\title{
Krüppel-Like Factor 9 Is Necessary for Late-Phase Neuronal Maturation in the Developing Dentate Gyrus and during Adult Hippocampal Neurogenesis
}

\author{
Kimberly N. Scobie, ${ }^{1,3}$ Benjamin J. Hall, ${ }^{5}$ Scott A. Wilke, ${ }^{6}$ Kristen C. Klemenhagen, ${ }^{1,3}$ Yoshiaki Fujii-Kuriyama, \\ Anirvan Ghosh, ${ }^{6}$ René Hen, ${ }^{1,2,3,4}$ and Amar Sahay ${ }^{1,3,4}$ \\ Departments of ${ }^{1}$ Neuroscience and Psychiatry and ${ }^{2}$ Pharmacology, Columbia University, ${ }^{3}$ Division of Integrative Neuroscience, ${ }^{4}$ New York State Psychiatric \\ Institute, New York, New York 10032, ${ }^{5}$ Department of Cell and Molecular Biology and the Neuroscience Program, Tulane University, New Orleans, \\ Louisiana 70118, ${ }^{6}$ Section of Neurobiology, Division of Biological Sciences, University of California, San Diego, La Jolla, California 92093, and \\ ${ }^{7}$ Tsukuba Advanced Alliance Research Center, University of Tsukuba, Tsukuba 305-8577, Japan
}

The dentate gyrus (DG) is modified throughout life by integration of new adult-born neurons. Similarities in neuronal maturation during DG development and adult hippocampal neurogenesis suggest that genetically encoded intrinsic regulatory mechanisms underlying these temporally distinct processes are conserved and reused. Here, we identify a novel transcriptional regulator of dentate granule neuron maturation, Krüppel-like factor 9 (Klf-9). We show that Klf-9 expression is induced by neuronal activity and as dentate granule neurons functionally integrate in the developing and adult DG. During development, dentate granule neurons lacking Klf-9 show delayed maturation as reflected by altered expression of early-phase markers, dendritic spine formation, and electrophysiological properties. Adult Klf-9-null mice exhibit normal stem cell proliferation and cell fate specification in the DG but show impaired differentiation of adult-born neurons and decreased neurogenesis-dependent synaptic plasticity. Behavioral analysis of Klf-9-null mice revealed a subtle increase in anxiety-like behavior and an impairment in contextual fear discrimination learning. Thus, Klf-9 is necessary for late-phase maturation of dentate granule neurons both in DG development and during adult hippocampal neurogenesis. Klf-9-dependent neuronal maturation may therefore represent a candidate regulatory mechanism underlying these temporally distinct processes.

\section{Introduction}

The dentate gyrus (DG) is the first stage of the hippocampal trisynaptic circuit and is the primary recipient of processed sensory information arriving from the entorhinal cortex. The DG is also one of two regions in the mammalian brain in which neurogenesis occurs in adulthood (Altman and Das, 1965; Eriksson et al., 1998). Therefore, DG development is not completed after formation of the DG per se, but continues throughout the life of the animal. Morphological and electrophysiological analyses of maturation of dentate granule neurons during development (Y. B. Liu et al., 1996; X. Liu et al., 2000; Rahimi and Claiborne, 2007) and in adulthood (Espósito et al., 2005; Laplagne et al., 2006; Zhao et al., 2006) have revealed striking similarities, al-

Received May 8, 2009; revised June 18, 2009; accepted June 22, 2009.

K.N.S. was supported by Ruth L. Kirschstein National Research Service Awards for Individual Predoctoral Fellows (F31). R.H. was supported by National Alliance for Research on Schizophrenia and Depression (NARSAD), New York Stem Cell Initiative, and National Institutes of Health Grant R01 MH068542. A.S. was supported by a 2006 and 2008 NARSAD Young Investigator Award, 2008 Sackler Institute of Columbia University Award, and National Institute of Mental Health Grant 1K99MH86615-01. We are grateful to Dr. Samuel Pleasure for providing the NeuroD- and NeuroD2-specific riboprobes. We thank members of the Hen Laboratory and Roman Giger for insightful comments on this project and this manuscript.

R.H. receives compensation as a consultant for BrainCells, Inc. and from AstraZeneca in relation to the generation of novel antidepressants.

Correspondence should be addressed to Dr. René Hen at the above address. E-mail: rh95@columbia.edu. D01:10.1523/JNEUROSCI.2260-09.2009

Copyright $\odot 2009$ Society for Neuroscience $\quad 0270-6474 / 09 / 299875-13 \$ 15.00 / 0$ though these processes occur in very different hippocampal niches. These observations underscore the notion that genetically encoded intrinsic mechanisms that regulate the maturation of dentate granule neurons during development are likely to be conserved and reused in adult hippocampal neurogenesis. Although the identities of these genetically encoded regulatory mechanisms remain mostly elusive, some clues have come from studies of transcriptional regulators of dentate granule neuron maturation.

The progression from neural stem cell to mature dentate granule neuron involves multiple intermediate stages that are defined by distinct physiological and morphological properties (Espósito et al., 2005; Song et al., 2005). These intermediate stages can be compartmentalized into an early phase that comprises processes such as stem cell proliferation, fate determination, and axonal elongation and a late phase that spans the acquisition of mature electrophysiological properties, dendritic elaboration, and integration into the hippocampal network. In contrast to our knowledge of early-phase transcription factors (TFs) in the developing (Miyata et al., 1999; Zhao et al., 1999; M. Liu et al., 2000; Oldekamp et al., 2004; Shen et al., 2006; Galichet et al., 2008) and adult DG (Maekawa et al., 2005), functional evidence for regulators of late-phase dentate granule neuron maturation is scarce (Barbosa et al., 2008). The identification of transcriptional regulators of late-phase dentate granule neuron maturation is likely to generate insights into mechanisms underlying integration of 
neurons into the hippocampal network both during development and in the adult brain.

Krüppel-like factor 9 (Klf-9) is a member of the Krüppel-like factor (Klf) family of evolutionarily conserved zinc finger transcription factors (Kaczynski et al., 2003) that has been implicated in mediating a diverse range of biological processes including stem cell maintenance (Jiang et al., 2008) and differentiation of T- and B-lymphocytes (Nikolcheva et al., 2002; Tabrizifard et al., 2004; Carlson et al., 2006; Good and Tangye, 2007). It has been proposed that Klf-9 can activate transcription as well as repress gene expression by directly interacting with the scaffold corepressor protein Sin3A (Zhang et al., 2001). Moreover, Klf-9 expression is sensitive to changes in thyroid hormone (Denver et al., 1999) and serotonin signaling (Khawaja et al., 2004) (A. Sahay and R. Hen, unpublished results), both of which are known to regulate dentate granule neuron maturation (Ambrogini et al., 2005; Wang et al., 2008). Here, we report that Klf-9 expression is influenced by neuronal activity and is restricted to terminal stages of differentiation of dentate granule neurons. We show that Klf-9 is necessary for late-phase maturation of developmentally generated and adult-born dentate granule neurons. Klf-9-dependent neuronal maturation may therefore represent a potential cellintrinsic regulatory mechanism underlying functional integration that is used both in DG development and during adult hippocampal neurogenesis.

\section{Materials and Methods}

Mice

Klf- $9^{-1-}$ mice were previously generated (Morita et al., 2003) and maintained on a mixed 129SvEv; C57BL/6J background. NeuroD2 ${ }^{-1-}$ mice were previously generated (Olson et al., 2001). The POMC- $\tau$-eGFP transgenic mouse line was obtained from GENSAT (http://www.gensat. org). Mice were housed four to five per cage in a $12 \mathrm{~h}$ (6:00 A.M. to 6:00 P.M.) light/dark colony room at $22^{\circ} \mathrm{C}$ and had ad libitum access to food and water. Experimental protocols were approved by the Institutional Animal Care and Use Committee at Columbia University and the New York State Psychiatric Institute.

\section{In situ hybridization and quantification}

Klf-9 riboprobe was generated from the $3^{\prime}$-untranslated region of mouse Klf-9 (NM 010638) corresponding to nucleotides 1500-1780. In situ hybridization (ISH) was performed on fresh frozen tissue as previously described (Sahay et al., 2003) using dioxygenin-labeled riboprobes. For perfused tissue, $35 \mu \mathrm{m}$ cryosections were mounted on charged glass ( $\mathrm{Su}$ perfrost Plus) slides and postfixed for $20 \mathrm{~min}$ in $4 \%$ paraformaldehyde (PFA). Sections were then washed in DEPC-treated PBS, treated with proteinase $\mathrm{K}(40 \mu \mathrm{g} / \mathrm{ml}$ final) for $30 \mathrm{~min}$ at room temperature (RT), washed again in DEPC-treated PBS, and then acetylated. The protocol for prehybridization, hybridization, and immunological detection was the same as that used for fresh frozen tissue ISH. Color reaction times were identical for both genotypes. MetaMorph software was used to quantify area of NeuroD expression in the developing DG. Briefly, the dorsal blade of the DG was traced from three matching hippocampal sections along the septotemporal axis (for each genotype) and opacity was computed after background subtraction.

\section{Immunohistochemistry and confocal microscopy}

Mice were anesthetized with ketamine/xylazine (100 and $7 \mathrm{mg} / \mathrm{kg}$, respectively) and transcardially perfused (cold saline, followed by $4 \%$ cold paraformaldehyde in PBS). Brains were postfixed overnight in 4\% PFA at $4^{\circ} \mathrm{C}$, then cryoprotected in $30 \%$ sucrose, and stored at $4^{\circ} \mathrm{C}$. Forty micrometer coronal serial sections of the entire hippocampus were obtained using a cryostat and stored in PBS. For glial fibrillary acidic protein (GFAP), neuronal nuclei (NeuN), and 5-bromo-2'-deoxyuridine (BrdU) triple immunohistochemistry, floating sections were used. After pretreatment in $1: 1$ formamide $/ 2 \times \mathrm{SSC}$ for $2 \mathrm{~h}$ at $65^{\circ} \mathrm{C}$, sections were treated with $2 \mathrm{~N} \mathrm{HCl}$ for $30 \mathrm{~min}$ at $37^{\circ} \mathrm{C}$ followed by immersion in $0.1 \mathrm{M}$ boric acid for $10 \mathrm{~min}$ at room temperature. Sections were rinsed three times in PBS and blocked in PBS with $0.1 \%$ Triton and 5\% normal donkey serum (NDS) for $2 \mathrm{~h}$ at RT. Incubation with primary antibodies was performed at $4^{\circ} \mathrm{C}$ overnight (rat anti-BrdU, 1:100, Serotec; rabbit anti-GFAP, 1:2000, Dako; mouse anti-NeuN, 1:500, Millipore Bioscience Research Reagents). The next day, sections were washed three times in PBS and incubated with fluorescent-coupled secondary antibodies (1: 400 in PBS; Jackson ImmunoResearch) for $2 \mathrm{~h}$ at RT. For Doublecortin (Dcx) immunohistochemistry, floating sections were first quenched to remove endogenous peroxidase activity $\left(1 \% \mathrm{H}_{2} \mathrm{O}_{2}\right.$ in $\mathrm{PBS} /$ methanol). Sections were then washed in PBS, blocked (PBS containing $0.3 \%$ Triton and $10 \% \mathrm{NDS}$ ), and incubated with primary antibody overnight at $4^{\circ} \mathrm{C}$ (goat anti-Dcx; 1:500; Santa Cruz). After washes in PBS, sections were incubated with horseradish peroxidase-coupled biotinylated secondary antibodies. After incubation with ABC solution (Vector Laboratories), the color reaction was performed using a DAB kit (Vector Laboratories). For calbindin, calretinin, $\beta$-galactosidase ( $\beta$-gal), serum response factor (SRF), green fluorescent protein (GFP), and Ki67 immunohistochemistry, floating sections were washed in PBS containing $0.3 \%$ Triton, blocked in PBS containing 0.3\% Triton and 10\% NDS, and then incubated overnight with mouse anti-calbindin (1:5000; Swant), goat anticalretinin (1:1000; Millipore Bioscience Research Reagents); rabbit antiSRF (1:500; sc-335; Santa Cruz), chicken anti- $\beta$-gal (1:500; Abcam), or rabbit anti-Ki67 (1:100; Vector Laboratories). Sections were then incubated with appropriate fluorophore-conjugated secondaries (Jackson ImmunoResearch). Bright-field images were obtained using a Zeiss Axioplan-2 upright microscope. Phenotyping of BrdU-expressing cells for coexpression with GFAP or NeuN in the granule cell layer of the DG entailed scanning of at least 50 cells from the dorsal and ventral hippocampus of each mouse using a Zeiss LSM 510 META scanning confocal microscope. Split-panel and $z$-stack analysis was performed using LSM510 image browser to determine ratios of BrdU/NeuN and BrdU/ GFAP double-labeled cells. For quantification of immature markers in the developing dentate gyrus, four matched sections per brain at postnatal day 20 (P20) were captured under identical exposure conditions $(n=$ 3 brains/genotype). MetaMorph software was used to trace the dorsal blade and quantify luminosity for calretinin immunoreactivity after background subtraction. An unbiased and blinded quantification protocol was used for all quantification.

\section{Morphological analysis of spines}

P14 mice were anesthetized and transcardially perfused with PBS followed by $4 \%$ PFA at pH 7.4 and postfixed in $4 \%$ PFA for $1 \mathrm{~h}$ on ice. One hundred micrometer coronal sections were cut using a vibratome and stored in PBS on ice. Penetrating microelectrodes were pulled from standard borosilicate capillary glass with filament ( $1 \mathrm{~mm}$ outer diameter; 0.58 $\mathrm{mm}$ inner diameter) and backfilled with Lucifer yellow dye (5\%). Slices were mounted on coverslips in PBS and dentate granule neurons in the outer one-half of the dorsal blade of the dentate gyrus were filled via iontophoresis under visual guidance. Sections were then postfixed an additional $15 \mathrm{~min}$ before being prepared for immunohistochemistry. Slices were blocked for $1 \mathrm{~h}$ on ice in 3\% BSA plus $0.4 \%$ Triton X-100 in PBS and incubated in primary antibody against Lucifer yellow (rabbit anti-LY; 1:1000; Abcam) overnight at $4^{\circ} \mathrm{C}$ in blocking solution. Slices were then washed three times for 20 min each time with block and incubated in secondary antibody (donkey anti-rabbit 555; 1:1000; Invitrogen) for $2 \mathrm{~h}$ at RT. Finally, slices were labeled with a Hoechst nuclear stain and mounted on slides for confocal microscopy.

\section{Imaging and analysis of spines}

Spines were imaged on a Leica SP2 confocal microscope under $63 \times$ magnification with $3 \times$ optical zoom. Images were collected from clearly identifiable granule neurons in the outer one-half of the dorsal blade of the dentate gyrus and imaged in the middle one-third of the dentate molecular layer as $z$-stacks with $0.5 \mu \mathrm{m}$ sections. Images were analyzed as confocal stacks using ImageJ software. For $30 \mu \mathrm{m}$ primary dendritic segments, measurements were taken of the length and head width of each spine. Head width measurements were obtained using a custom ImageJ plugin (www.ghoshlab.org). 


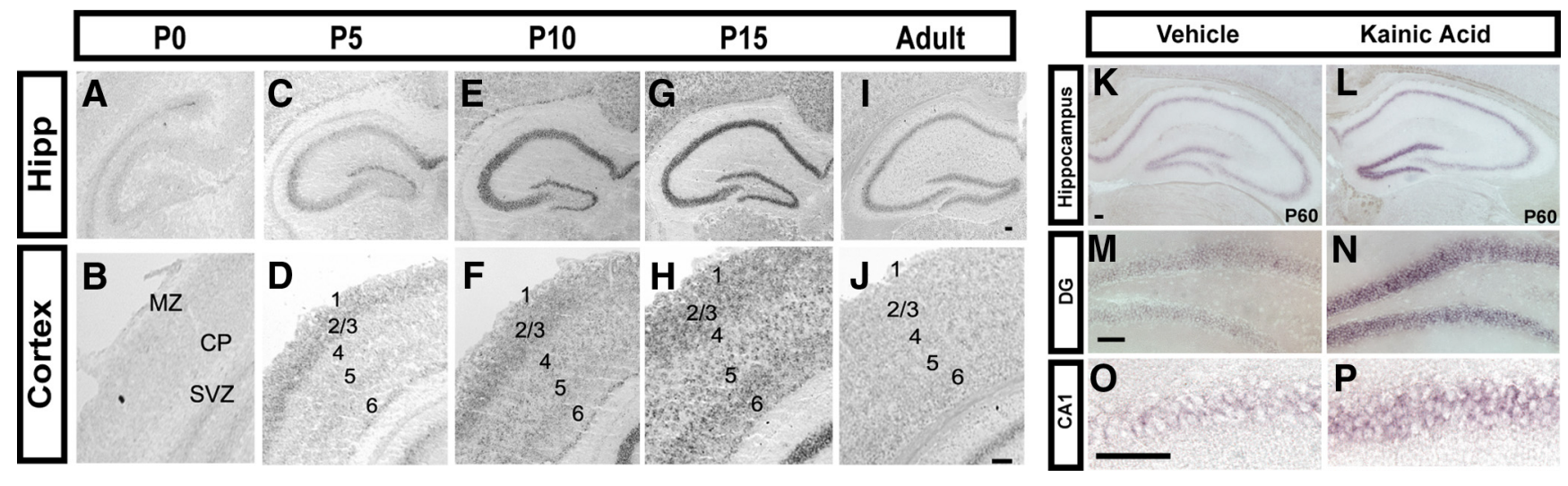

Figure 1. KIf-9 expression is upregulated during the early-postnatal period and by neuronal activity in vivo. $A, B, A t P 0, K l f-9$ is expressed at very low levels in the forebrain. $C, D, A t P 5, K I f-9$ mRNA is detected in $C A$ and DG subfields $(\boldsymbol{C})$ and layers $1,2 / 3$, and 6 of the neocortex (D). $\boldsymbol{E}, \boldsymbol{F}, K / f-9$ expression is increased at $P 10$ in all subfields of the hippocampus $(\boldsymbol{E})$ and layers $1,2 / 3,5$, and 6 of the neocortex $(\boldsymbol{F}) . \mathbf{G}, \boldsymbol{H}, \mathbf{K I F - 9}$ expression reaches the highest levels in the hippocampus $(\boldsymbol{G})$ and neocortex $(\boldsymbol{H})$ by $\mathbf{P} 15 . \boldsymbol{I}, \boldsymbol{J}, \mathbf{K I f}-9$ expression decreases in adulthood. $\boldsymbol{K}-\boldsymbol{P}, \boldsymbol{K I f}-9$ expression is upregulated in all subfields of the hippocampus after kainic acid-induced seizures $(\boldsymbol{L})$ compared with vehicle-treated mice $(\boldsymbol{K}) . \boldsymbol{M}, \boldsymbol{N}$, Magnification $(20 \times)$ of the $D G$ after vehicle $(\boldsymbol{M})$ and kainic acid treatment $(\boldsymbol{N}) . \mathbf{O}, \boldsymbol{P}$, Magnification $(20 \times)$ of $\mathrm{CA} 1$ after vehicle treatment $(\mathbf{0})$ and kainic acid treatment $(\boldsymbol{P}) . n=3$ mice per group. Scale bar, $100 \mu \mathrm{m}$.

\section{Electrophysiology}

Electrophysiological studies in the developing DG. Whole-cell voltage recordings were used to examine passive and active electrical properties of dentate granule neurons in the developing DG of $K l f-9^{-1-}$ mice, compared with littermate controls $\left(K l f-9^{+/+}\right)$. Mice aged P14-P17 were deeply anesthetized with isoflurane and then rapidly decapitated. Brain slices were cut in the coronal plane at a thickness of $350 \mu \mathrm{m}$ using a vibrating microtome (VT-1200; Leica Microsystems). Slicing was performed in an ice-cold artificial CSF (ACSF) with the following ionic composition (concentrations in $\mathrm{mM}$ ): $124 \mathrm{NaCl}, 5 \mathrm{KCl}, 26 \mathrm{NaHCO}_{3}, 1.25$ $\mathrm{NaH}_{2} \mathrm{PO}_{4}, 10$ glucose, $6 \mathrm{MgCl}_{2}, 1 \mathrm{CaCl}_{2}$. Slices were moved directly to a holding chamber and maintained for at least $0.5 \mathrm{~h}(0.5-3 \mathrm{~h})$, and then transferred to a recording chamber. In both the holding chamber and recording chamber, slices were submerged in a standard recording solution (at room temperature) with the following ionic composition (concentrations in mM): $124 \mathrm{NaCl}, 5 \mathrm{KCl}, 26 \mathrm{NaHCO}_{3}, 1.25 \mathrm{NaH}_{2} \mathrm{PO}_{4}, 10$ glucose, $3 \mathrm{MgCl}_{2}, 2 \mathrm{CaCl}_{2}$, bubbled constantly with $95 \% \mathrm{O}_{2} / 5 \% \mathrm{CO}_{2}$ gas. Dentate granule neurons were visualized and their relative cell body position within the granule cell layer was determined by infrared-differential interference contrast imaging using an upright, fixed-stage microscope (BX-51; Olympus). Whole-cell patch electrodes were pulled from borosilicate glass $(1.5 \mathrm{~mm}$ outer diameter and $1.16 \mathrm{~mm}$ inner diameter; Warner Instruments) to resistances ranging from 5 to $7 \mathrm{M} \Omega$. The intracellular recording solution contained the following (in $\mathrm{mM}$ ): 125 K-gluconate, $8 \mathrm{NaCl}, 5$ D-glucose, 5 HEPES, 0.5 ATP, $0.3 \mathrm{GTP}, 1 \mathrm{EGTA}$ at $\mathrm{pH}$ 7.3. Access resistances on break-in ranged from 15 to $27 \mathrm{M} \Omega$. Recordings were made using a PC-505 amplifier (Warner Instruments) and acquired through custom software routines written in Igor Pro (Wavemetrics), using NIDAQ tools to access a PCI-based digitizing board (PCI-1200; National Instruments). Current-clamp recordings in response to $50 \mathrm{pA}$, square-wave current injections ( $3 \mathrm{~s}$ in duration, both depolarizing and hyperpolarizing steps) were used to examine the following parameters: cell input impedance, cell capacitance, membrane time constant, spike threshold, spike amplitude, and spike width at halfamplitude. Input impedance was calculated from the negative current injections by measuring the average steady-state voltage during the step, and time constants were measured off the initial charging phase of the response. Spike parameters were measured from the first action potential (AP) in the train in response to the depolarizing current step.

Electrophysiological studies in the adult DG. Electrophysiological recordings in the DG were performed as previously described (Saxe et al., 2006) using 3- to 4-month-old mice (five male mice per genotype; $n=10$ slices WT, 14 slices $\mathrm{KO})$.

\section{BrdU injections}

For analysis of stem cell proliferation in the adult DG, 6-month-old mice were injected with $200 \mathrm{mg} / \mathrm{kg} \mathrm{BrdU}$ (Roche) and perfused after $2 \mathrm{~h}(n=$
$5 \mathrm{Klf}-\mathrm{9}^{-/-} ; n=4 \mathrm{Klf}-\mathrm{9}^{+/+}$). For assessment of survival of adult-born neurons, BrdU was administered at $50 \mathrm{mg} / \mathrm{kg}$ twice a day intraperitoneally for $10 \mathrm{~d}\left(100 \mathrm{mg} \cdot \mathrm{kg}^{-1} \cdot \mathrm{d}^{-1}\right.$ in $0.9 \% \mathrm{NaCl} ; n=4$ per genotype $)$ for the 2 week time point and once a day for $3 \mathrm{~d}\left(150 \mathrm{mg} \cdot \mathrm{kg}^{-1} \cdot \mathrm{d}^{-1}\right.$ in $0.9 \%$ $\mathrm{NaCl})$ for the 4 week ( $n=5$ per genotype) and 6 week time points $(n=$ 3 per genotype). Four- to 6 -month-old mice were used for adult-born neuron survival experiments.

\section{Birthdating of adult-born dentate granule neurons}

Klf-9 $9^{\text {LacZ/+ }}$ mice were injected with BrdU $(150 \mathrm{mg} / \mathrm{kg})$ once a day for $4 \mathrm{~d}$ and were analyzed at 2, 3, 5, and 7 weeks after the last BrdU injection $(n=$ 4 per group). Forty micrometer coronal serial sections of the entire perfused hippocampus were obtained using a cryostat and stored in PBS. Sections were processed for anti- $\beta$-gal and BrdU double immunohistochemistry and scanned by confocal microscopy (Zeiss LSM 510 META). Split-panel and $z$-stack analysis was performed using LSM510 image browser to identify BrdU-positive cells that were immunoreactive for $\beta$-gal (30-40 BrdU + cells in the DG granule cell layer from dorsal and ventral hippocampal sections).

\section{Analysis of hippocampal mossy fibers}

The area of mossy fiber termination zone (as defined in Fig. 4) and of CA3ab was measured using NIH ImageJ from 10 to 12 hippocampal sections per mouse brain. $n=3$ mice (P20) per group were used for the analysis.

\section{Golgi impregnation, Sholl analysis, and quantification of dendritic} spine density in adult mice

FD Neurotech kit was used for Golgi impregnation of tissue after considerable optimization of several parameters. After impregnation, vibratome-generated $150 \mu \mathrm{m}$ coronal sections were mounted on $3 \%$ gelatin-coated slides. Dentate granule neurons $(n=9-10$ per mouse) were traced using camera lucida at $400 \times$ magnification (Neurolucida; MicroBrightField). Neurons chosen for tracing met the following criteria: (1) they were completely impregnated with Golgi stain, (2) they were unobscured by other impregnated neurons or precipitant, (3) 70\% of the dendritic tree was visible within the plane of focus, and (4) dentate granule neurons must be located in the outer one-half of the granule cell layer. Using NeuroExplorer software (MicroBrightField), dendritic complexity (Sholl analysis), dendritic length, cell body area, and spine density were calculated. The Sholl analysis defines dendritic complexity by the number of dendritic branch points at fixed intervals from the cell bodies. For analysis of dendritic spines of dentate granule neurons, two segments of distal dendrites in the outer molecular layer of two granule neurons were traced at $100 \times$ for a total of four segments per mouse times nine mice per genotype. All samples were number coded, and analysis was done blind to genotype. 
Seizure induction protocol

A kainic acid seizure induction protocol was used (Zagulska-Szymczak et al., 2001). Mice were injected with kainic acid $(20 \mathrm{mg} / \mathrm{kg}$; K0250; Sigma-Aldrich) or PBS (vehicle) and killed $2 \mathrm{~h}$ after seizures. Brains were fresh frozen immediately, sectioned, and processed for in situ hybridization.

\section{Behavioral analysis}

For all behavioral tasks, we used adult 8- to 10week-old Klf-9 $9^{-1-}$ and Klf- $9^{+/+}$littermates.

Open field. Mice were single-housed without food in the room adjacent to the testing room for at least $1 \mathrm{~h}$ before testing. Motor activity over 60 min was quantified in four Plexiglas open-field boxes of $43.2 \times 43.2 \mathrm{~cm}^{2}$ (lux 3-4/ box; MED Associates). Two sets of 16 pulsemodulated infrared photobeams were placed on opposite walls $2.5 \mathrm{~cm}$ apart to record $x-y$ ambulatory movements. Activity chambers were computer interfaced for data sampling at $100 \mathrm{~ms}$ resolution. The software defined grid lines that divided each open field into center and surround regions, with each of four lines being $11 \mathrm{~cm}$ from each wall. Dependent measures were the number of entries into the center, the distance traveled in the center, total time spent in the center, and distance traveled in the center divided by total distance traveled. Overall motor activity was quantified as the total distance traveled (in centimeters).

Light/dark choice task. The light/dark test ( $n=12-16$ per group) was conducted in an open-field chamber measuring $43.2 \times 43.2 \mathrm{~cm}$ (MED Associates) with a white floor and clear walls. A dark plastic box that is opaque to visible light but transparent to infrared covered one-half of the chamber area, thus creating dark and light compartments of equal size. An opening at floor level in the center of one wall of the dark compartment allowed passage between the light and dark compartments. The light compartment was brightly illuminated with an $8 \mathrm{~W}$ fluorescent tube (550-850 lux). The test was performed in a quiet, darkened room, and the mice were kept in this room at least $1 \mathrm{~h}$ before the test without food. Between each trial, the whole apparatus was cleaned. At the beginning of the test, the mouse was placed in the dark compartment and allowed to freely explore both compartments for $5 \mathrm{~min}$. Ambulation distance and time spent in the dark and the light compartments were recorded.

Elevated plus maze and novelty suppressed feeding. Tests were performed as previously described (Gross et al., 2002; Santarelli et al., 2003).

Forced-swim test. Mice were placed in transparent plastic buckets $(19 \mathrm{~cm}$ diameter; $23 \mathrm{~cm}$ deep) filled with $23-25^{\circ} \mathrm{C}$ water for $6 \mathrm{~min}$ and the animal's behavior was recorded using an automated video-tracking system. Testing was performed over 2 consecutive days with the first day serving the purpose of preexposure. Mobility (swimming and climbing behaviors) on the second day was analyzed using ViewPoint Life Sciences software.

One-trial contextual fear conditioning. Conditioning was conducted on one side of a MED

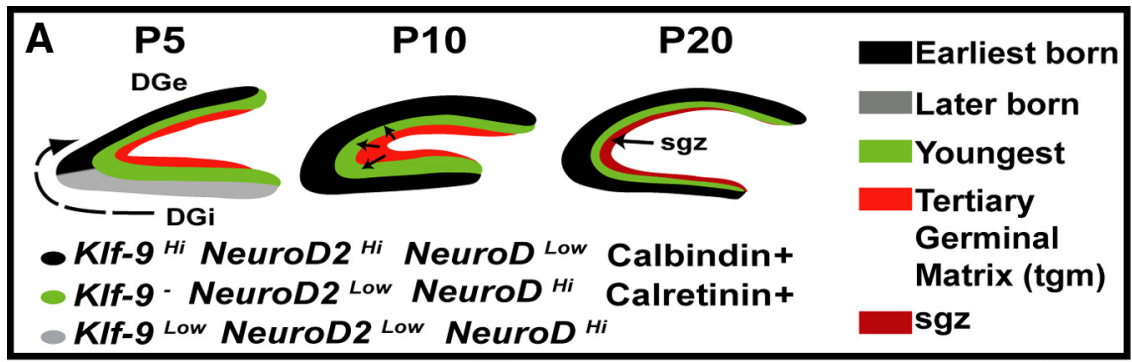

\section{P15 KIf-9 lacZ/+}

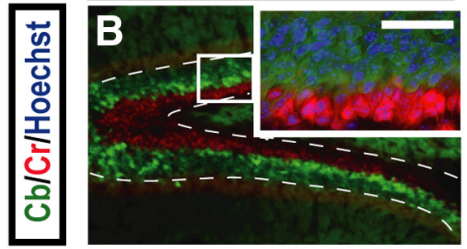

P40 KIf-9 lacZ/+
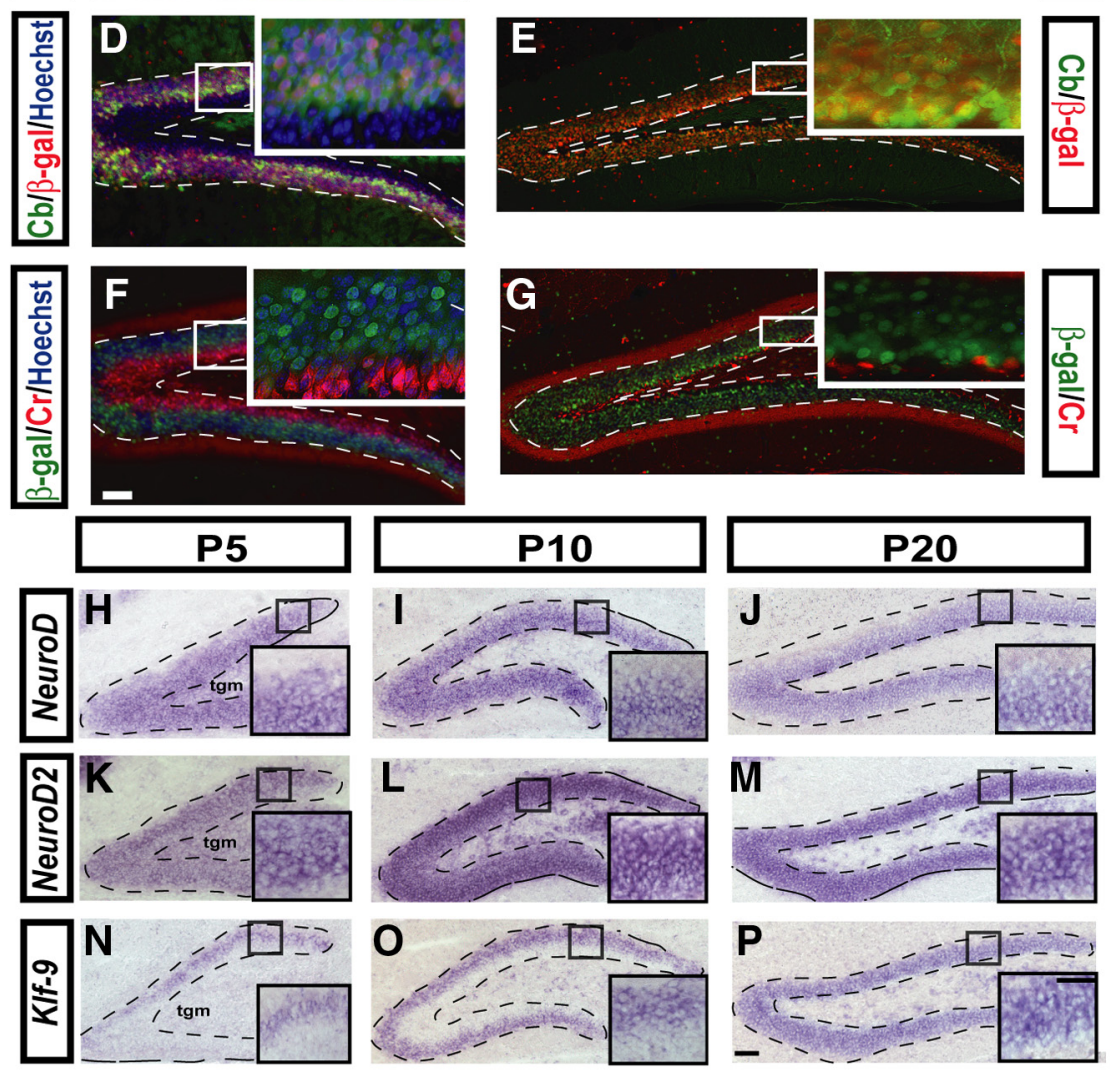

Figure 2. KIf-9 expression defines a novel late-stage window of dentate granule neuronal maturation. $A$, Schematic of DG development illustrating the radial and tangential morphogenetic gradients and summarizing NeuroD, NeuroD2, calretinin, calbindin, and KIf-9 expression in the developing DG. At P5, the earliest-born cells occupy the upper crest of the forming DG (shown in black). The later born cells, shown in gray, migrate tangentially from the lower blade of the forming DG toward the upper blade. Youngest cells, shown in green, are born and migrate radially from the tertiary germinal matrix (tgm), shown in red, toward the dorsal crest. By P10, cells are born in the tgm and migrate into the inner one-half of the DG, in which younger cells reside. The inner one-half of the DG granule cell layer ( $\mathrm{gcl}$ ) consists of younger cells and the outer one-half consists of older cells. By P20, the proportion of the dentate gyrus that consists of older cells is increased to approximately two-thirds of the gcl. The younger cells make up the inner one-third of the $\mathrm{gcl}$. At this time, the precursor cells settle in a region along the hilar side of the granule cell layer termed the SGZ. $\boldsymbol{B}-\boldsymbol{G}$, Calbindin, calretinin, and $\beta$-galactosidase immunohistochemistry on hippocampal sections of $K I f-9^{+/ l a c Z}$ mice. $B, C$, Calretinin (red) and calbindin (green) immunoreactivity at P15 (B) and P40 (C). D, E, Calbindin (green) and $\beta$-galactosidase immunoreactivity (red) at P15 (D) and P40 (E). $\boldsymbol{F}, \boldsymbol{G}, \boldsymbol{\beta}$-Galactosidase (green) and calretinin (red) at P15 (F) and P40 (G). H-P, In situ hybridization of NeuroD, NeuroD2, and KIf-9 during postnatal development of the DG. $\boldsymbol{H}-\boldsymbol{J}$, Expression of NeuroD at P5 $(\boldsymbol{H}), \mathrm{P} 10(\boldsymbol{I})$, and P20 (J). $\boldsymbol{K}-\boldsymbol{M}$, Expression of NeuroD2 at P5 $(\boldsymbol{K}), \mathrm{P} 10(\boldsymbol{L})$, and P20 (M). $\boldsymbol{N}-\boldsymbol{P}, \boldsymbol{K l f}-9$ expression at P5 $(\boldsymbol{N}), \mathrm{P} 10(\mathbf{O}), \mathrm{P} 20(\boldsymbol{P})$. Scale bars: $\boldsymbol{B}-\boldsymbol{P}, 100 \mu \mathrm{m} ; \boldsymbol{B}-\boldsymbol{P}$, insets, $100 \mu \mathrm{m}$. 

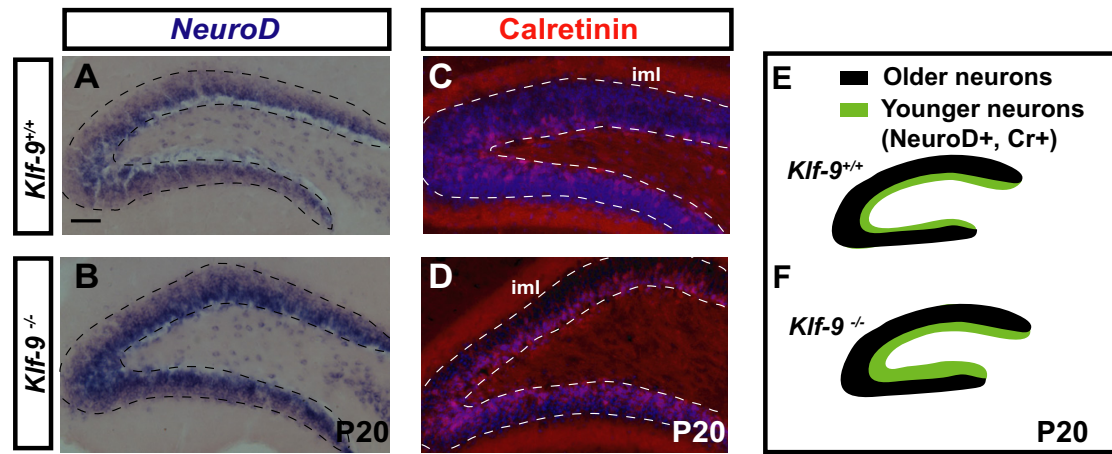

G
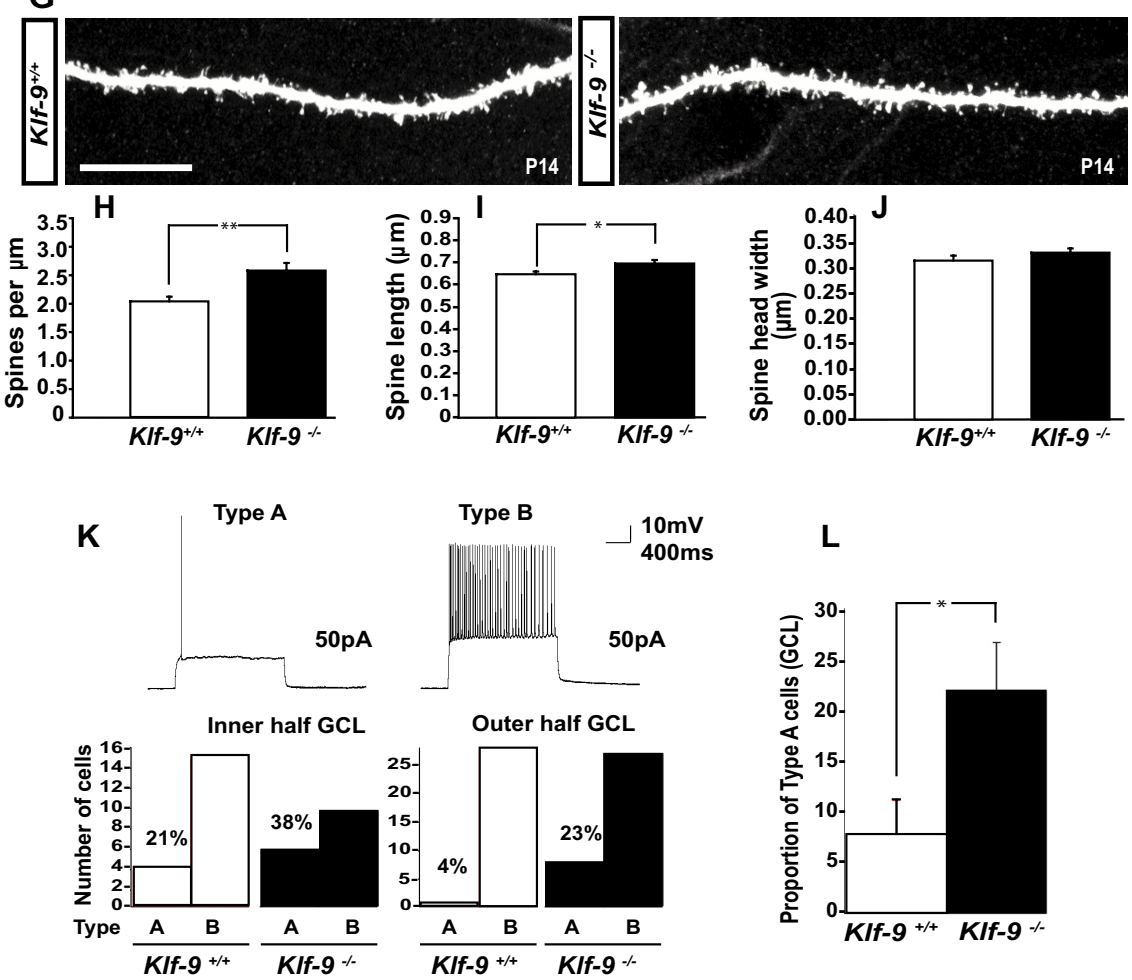

$\mathbf{L}$

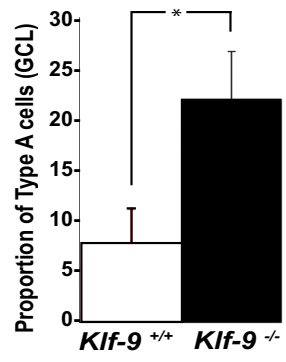

Figure 3. Dentate granule neurons lacking KIf-9 show prolonged expression of early-phase markers, have longer dendritic spines, and exhibit altered action potential response properties during DG development. $A, B$, In situ hybridization for NeuroD showing an expansion in the NeuroD population in the DG of P2O KIf- $9^{-/-}$mice $(\boldsymbol{B})$ compared with $K I f-9^{+/+}$mice $(\boldsymbol{A}) . \boldsymbol{C}, \boldsymbol{D}$, Immunohistochemistry for calretinin showing an expansion in the population of calretinin-expressing cells in P2O KIf-9- ${ }^{-1-}$ mice (D) compared with KIf-9 $9^{+/+}$mice $(\boldsymbol{C}) \cdot \boldsymbol{E}, \boldsymbol{F}$, Schematic summarizing NeuroD and calretinin expression in the DG of $K I f-9^{+/+}$mice $(\boldsymbol{E})$ and $K I f-9^{-/-}$mice $(\boldsymbol{F})$ at P20; $n=3$ mice/ genotype. G, Representative image of a luciferase-filled dendrite of a KIf-9 $9^{+/+}$(left) and $K I f-9^{-1-}$ (right) dentate granule neuron at P14. $H-J$, Quantification of spine density, $K I f-9^{+/+}, 2.08 \pm 0.08$ spines per micrometer; $K I$ If $-9^{-/-}, 2.64 \pm 0.13$ spines per micrometer; $p=$ 0.002 , unpaired ttest. I, Spine length, KIf- $9^{+/+}, 0.66 \pm 0.012 \mu \mathrm{m} ; K$ Klf- $9^{-I-}, 0.71 \pm 0.01 \mu \mathrm{m} ; p=0.019$, unpaired ttest.J, Spine head width, Klf- $9^{+/+}, 0.32 \pm 0.01 \mu \mathrm{m} ; K / f-9^{-/-}, 0.34 \pm 0.008 \mu \mathrm{m} ; p>0.05$, unpaired $t$ test; $n=3$ mice per genotype. $K, L$, Based on AP response properties of dentate granule neurons (P14-P17) in response to current injection (3 s; $50 \mathrm{pA})$, cells in DG were classified as "type $A^{\prime \prime}$ or "type B." Of cells in the inner one-half of the DG, 38\% are type A in KIf-9-null mice compared with $21 \%$ in controls. Twenty-three percent of cells in the outer one-half of DG are type A in KIf- $9^{-1-}$ mice in contrast to only $4 \%$ in controls. The DG of $K f-9^{-1-}$ mice have a significantly greater proportion of type A cells than controls $(\boldsymbol{L})(p=0.029$, unpaired $t$ test; $n=9$ mice per group). Results are mean \pm SEM. Scale bar: $A-D, 100 \mu \mathrm{m} ; \boldsymbol{G}, 10 \mu \mathrm{m} .{ }^{*} p<0.019(\boldsymbol{I}){ }^{* *} p<0.002(\boldsymbol{H})$.

Associates shuttle box (ENV-010MC; $20.3 \times 15.9 \times 21.3 \mathrm{~cm}$ high) with a clear Plexiglas wall, three aluminum walls, and a stainless-steel grid as a floor. The chamber was lit from above with a light (CM1820 bulb), ventilated with a fan, and encased by a sound-dampening cubicle. On the days of testing, mice were brought out of the vivarium and allowed to habituate for an hour outside the testing room before starting the experiment. Mouse behavior was recorded by digital video cameras mounted above the conditioning chamber. Freezeframe and Freezeview software (Actimetrics) were used for recording and analyzing freezing behavior, respectively. The one-trial contextual fear conditioning protocol entailed delivery of a single $2 \mathrm{~s}$ footshock of $0.75 \mathrm{~mA}$, $185 \mathrm{~s}$ after placement of the mouse in the training context. The mouse was taken out $15 \mathrm{~s}$ after termination of the footshock and returned to its home cage. For the training context, the fan and lights were on, stainless-steel grids were exposed, and a mild lemon scent was used as an olfactory cue. Ethanol (70\%) was used to clean grids in between runs. Mice were brought into the room individually in a holding cage. For the novel context, the stainless-steel grid floor was covered with a plastic panel and cage bedding. Two of the chamber walls were covered using plastic inserts and the chamber fan and lights were turned off. The chamber door was left open during testing. A mild anise scent was used as an olfactory cue and a nonalcoholic antiseptic was used to clean the chamber in between runs. Mice were brought into the testing room in cardboard buckets by a different handler, and the testing room was dimly lit before placement of the mice in the testing chambers. For the three tone-shock background fear conditioning protocol, three tones $(20 \mathrm{~s} ; 80 \mathrm{~dB} ; 2$ $\mathrm{kHz})$ coterminated with $1 \mathrm{~s}$ shocks $(0.5 \mathrm{~mA})$, each spaced apart by 140,170, and 110 s successively. For testing of cued fear conditioning, the tone was presented twice for $20 \mathrm{~s}$ at 130 and $300 \mathrm{~s}$ into the testing session. Freezing levels were quantified for $20 \mathrm{~s}$ before onset of tone.

Contextual fear discrimination learning. This procedure was adapted from previous studies (Frankland et al., 1998; Wang et al., 2009). Mice were preexposed to the similar context (which shared many features with the training context) for $5 \mathrm{~min} 24 \mathrm{~h}$ before the start of the discrimination learning paradigm. Preexposure to the similar context was done as it has been shown to facilitate generalization of fear conditioning to similar contexts (Rudy and O'Reilly, 1999). The training context was identical with that used in contextual fear conditioning. For the similar context, the stainless grid floor was exposed, one plastic insert was used to cover one of the walls, the house fan and lights were left on, and mice were brought into the testing room in holding cages. As with the training session, $70 \%$ ethanol was used to clean the grid in between runs. During the training phase of the discrimination learning paradigm (days 5 and 6), mice were exposed to the training context in the morning and to the similar context $3 \mathrm{~h}$ later. The mice always received a single $2 \mathrm{~s}$ footshock in the training context $(0.75$ $\mathrm{mA}$ ) but never in the similar context. On day 7 (testing), mice were placed in the training context in which they received a shock and were then exposed to the similar context.

\section{Statistical analysis}

Statistical analysis was performed using Statview software or Microsoft Excel. Statistical significance was assessed by unpaired two-tailed Student's $t$ tests or ANOVA followed by Fisher's post hoc tests, where appropriate.

\section{Results}

$K l f-9$ expression is transiently upregulated during the early-postnatal period and is induced by neuronal activity

To begin to understand the role of Klf- 9 in neuronal maturation, we first examined the expression of Klf-9 in the mouse forebrain 
during the early-postnatal period by in situ hybridization using a riboprobe specific for Klf-9 (supplemental Fig. 1A,B, available at www.jneurosci.org as supplemental material). At P0, Klf-9 is expressed at very low to negligible levels (Fig. $1 A, B$ ). By P5, Klf-9 mRNA is detected in the hippocampus and layers $2 / 3$ and 6 of the neocortex (Fig. 1C,D). Between P10 and P15, Klf-9 expression increased in all hippocampal subfields (Fig. $1 E, G$ ) and cortical layers $2 / 3,4,5$, and 6 (Fig. $1 F, H$ ). In adulthood, Klf- 9 expression had abated to lower levels (Fig. 1I,J). The upregulation of Klf-9 expression during the earlypostnatal period, when activity-dependent processes shape neural circuits, is suggestive of a role for Klf-9 in neuronal maturation. To directly test whether Klf-9 expression is regulated by neuronal activity, we analyzed Klf- 9 expression in the hippocampus after kainic acid-induced seizures (Zagulska-Szymczak et al., 2001). We found that Klf-9 levels increased $2 \mathrm{~h}$ after seizures compared with vehicle-injected controls (Fig. $1 K, L$ ). This increase in Klf-9 expression was evident in both the DG and CA1 subfields of the hippocampus (Fig. $1 M-P$ ). Our results, together with a recent study that showed upregulation of $K l f-9$ expression after membrane depolarization of cultured cortical neurons (Lin et al., 2008), indicate that Klf-9 expression is induced by neuronal activity both in vitro and in vivo.

\section{Klf-9 expression is restricted to the} late phase of dentate granule neuron maturation during DG development The upregulation of Klf-9 expression during the early-postnatal period, when activitydependent processes shape neural circuits, and by neuronal activity is suggestive of a role for Klf-9 in neuronal maturation. Since DG connectivity is established mostly during the early-postnatal period in rodents, we examined the role of $K l f-9$ in dentate granule neuron maturation. We first performed a detailed examination of $K l f-9$ expression in the DG during development.

During DG development, two distinct morphogenetic gradients (radial and tangential) that reflect cells of different ages and maturity are evident (Altman and Bayer, 1990) (Fig. 2A). To define the window of dentate granule neuronal maturation during which $K l f-9$ is expressed, we compared $K l f-9$ expression with that of calcium binding proteins, calretinin and calbindin, which are expressed in immature and mature neurons, respectively (Bender et al., 2001; Brandt et al., 2003). We took advantage of Klf-9 lacZ knock-in mice (Klf-9lacZ/+ $)$ (Morita et al., 2003) in which lacZ expression recapitulates $K l f-9$ mRNA expression (data not shown). At P15, calbindin immunoreactivity is excluded from the immature cal-
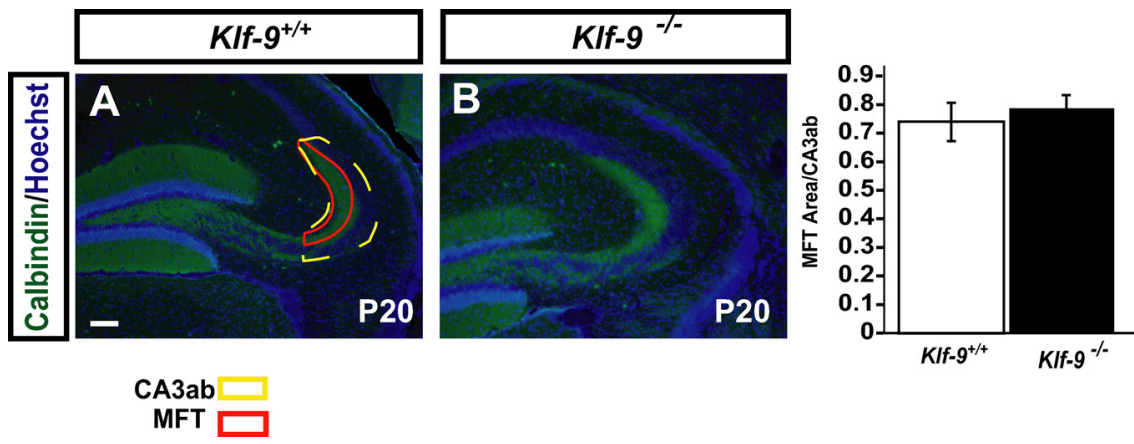

Figure 4. Mossy fiber projections develop normally in KIf-9-null mice. $\boldsymbol{A}$, Representative micrograph of calbindin immunohistochemistry showing normal mossy fiber targeting in KIf-9 $9^{-I-}$ mice (right) compared with Klf- $9^{+1+}$ mice (left) at P20. B, Mossy fiber terminal area is not different between $K I f-9^{+/+}$and $K I f-9^{-1-}$ mice $(p>0.05$, unpaired $t$ test $) ; n=3$ mice per group. Results are mean \pm SEM. Scale bar, $100 \mu \mathrm{m}$.
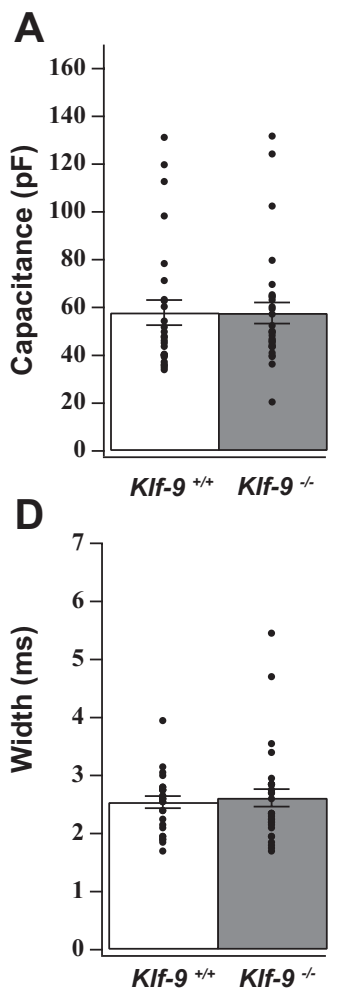

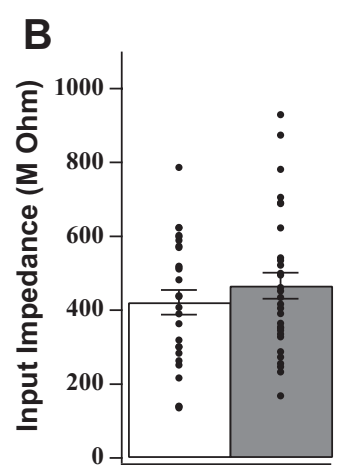

$K I f-9^{+/+} K I f-9^{\%}$

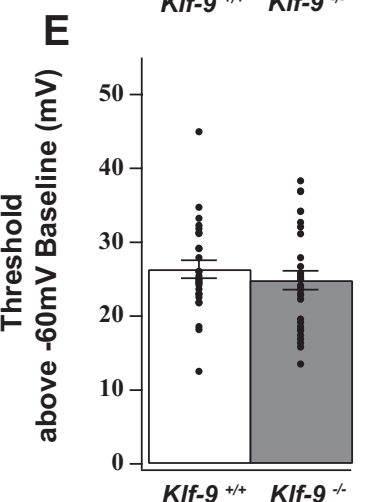

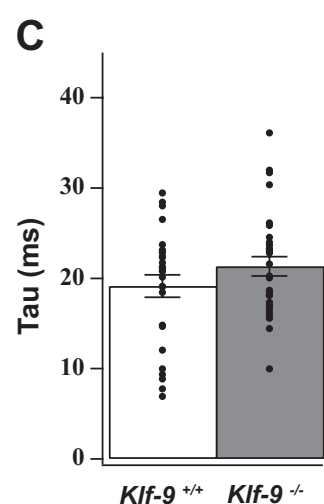

$F$

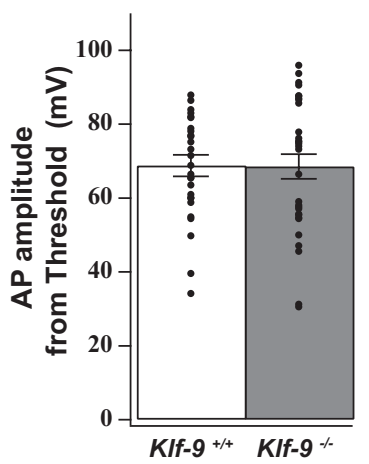

Figure 5. Klf-9 loss of function does not affect passive membrane properties and action potential characteristics. $\boldsymbol{A}-\boldsymbol{C}$, Passive membrane properties as measured by whole-cell voltage recordings from DG granule neurons (P14 -P17) are not different between $K I f-9^{+/+}$and $K I f-9^{-I-}$ mice. A, Capacitance of DG granule neurons recorded from Klf- $9^{+/+}$versus $K I f-9^{-I-}$ mice $(57.91 \pm 5.26 \mathrm{pF}$ vs $57.66 \pm 4.44 \mathrm{pF}) ; p=0.98$, unpaired $t$ test. $\boldsymbol{B}$, Impedance of DG granule neurons recorded from $K I f-9^{+/+}$ versus KIf-9 ${ }^{-1-}$ mice $(421.55 \pm 33.39 \mathrm{M} \Omega$ vs $466.24 \pm 35.26 \mathrm{M} \Omega) ; p=0.36$, unpaired $t$ test. $C$, Time constant of DG granule neurons recorded from $K I f-9^{+/+}$versus $K I f-9^{-/-}$mice (19.15 $\pm 1.24 \mathrm{~ms}$ vs $\left.21.33 \pm 1.07 \mathrm{~ms}\right) ; p=0.19$, unpaired $t$ test. $\boldsymbol{D}-\boldsymbol{F}$, Action potential characteristics. D, Action potential width: $2.54+0.1 \mathrm{~ms}\left(K l f-9^{+/+}\right)$versus $2.62+0.15 \mathrm{~ms}\left(K l f-9^{-\prime-}\right) . E_{,}$Action potential threshold ofDG granule neurons recorded from KIf- $9^{+/+}$versus KIf- $9^{-1-}$ mice $(26.36 \pm 1.20 \mathrm{mV}$ vs $24.85 \pm 1.28 \mathrm{mV})$; $p=0.4$, unpaired $t$ test. $\boldsymbol{F}$, Action potential amplitude of DG granule neurons recorded from Klf-9 ${ }^{+/+}$versus Klf-9 $9^{-1-}(68.77 \pm$ $2.93 \mathrm{mV}$ vs $68.53 \pm 3.35 \mathrm{mV}$ ); $p=0.92$, unpaired $t$ test. $n=27$ (control) and 30 (KO) cells. Results are mean \pm SEM.

retinin positive granule cells in the inner one-half of the DG (Fig. $2 B)$. At P40, calretinin immunoreactivity is seen only in newly born neurons in the SGZ, whereas most of the mature granule neurons express calbindin (Fig. 2C). Analysis of $\mathrm{Klf}-9^{\text {lac } /++}$ mice at $\mathrm{P} 15$ and $\mathrm{P} 40$ revealed overlap of $\beta$-galactosidase and calbindin (Fig. $2 D, E$ ), but not calretinin immunoreactivity in the DG (Fig. $2 F, G)$. In contrast, analysis of another regulator of neuronal maturation, SRF, revealed SRF immunoreactivity in both calretinin- 

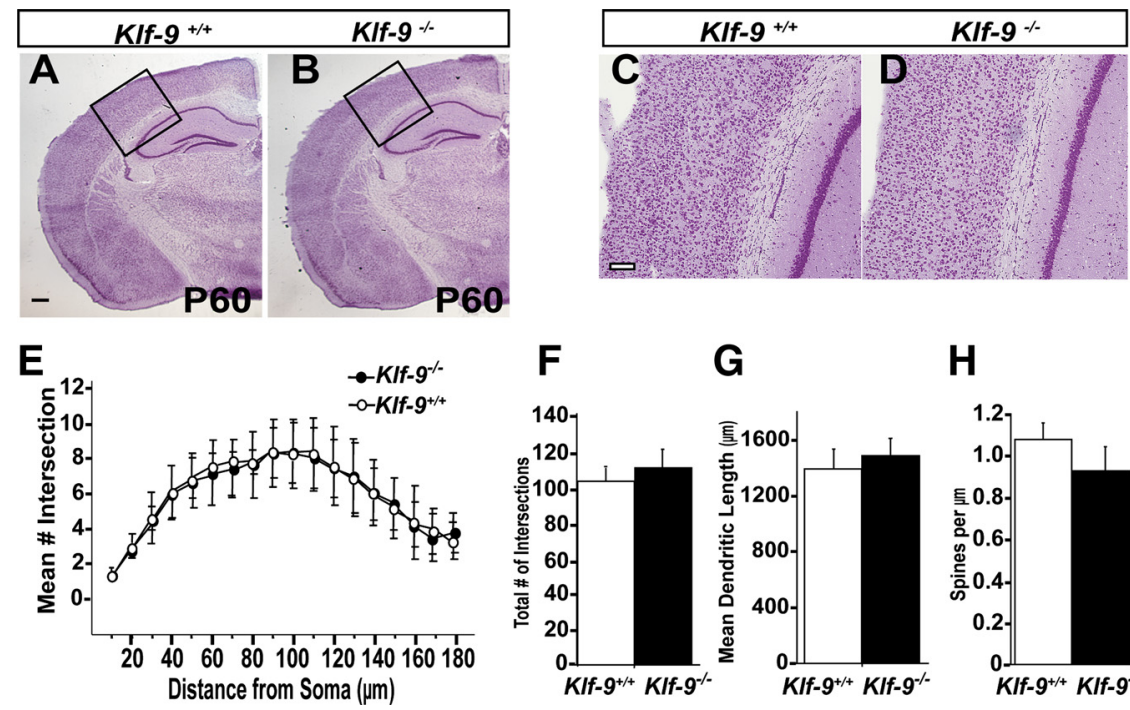

Figure 6. Developmentally born dentate granule neurons in adult KIf-9-null mice exhibit normal dendritic length and complexity and dendritic spine density. $\boldsymbol{A}-\boldsymbol{D}$, Niss stain of $K I f-9^{+/+}(\boldsymbol{A})$ and $K I f-9^{-1-}(\boldsymbol{B})$ mouse brain at P60. C, D, High magnification of neocortex showing intact cortical lamination in $K I f-9^{-1-}$ mice compared with controls. $\boldsymbol{E}-\boldsymbol{H}$, Golgistained dentate granule neurons from adult $K I f-9^{+/+}$and $K I f-9^{-1-}$ mice traced by Neurolucida and analyzed for branching, dendritic length, and spine density using NeuroExplorer software. $\boldsymbol{E}$, Sholl analysis of apical dendrites of DG granule neurons reveals normal dendritic complexity in $K I f-9^{-1-}$ mice compared with controls. $n=9$ neurons per mouse; $n=6$ mice per genotype. $\boldsymbol{F}-\boldsymbol{H}, \mathrm{KIf-} \mathbf{9}^{+/+}$and $K I f-9^{-I-}$ DG granule neurons show comparable mean number of intersections (branching) of dendrites (KIf-9 $9^{+/+}, 105.4 \pm 7.8 ;$ KIf-9-1-, $112.4 \pm 9.5 ; n=9$ neurons per mouse, $n=6$ mice per genotype) $(\boldsymbol{F})$; dendritic length of DG granule neurons (KIf-9 ${ }^{+/+}, 1397 \pm 137 \mu \mathrm{m} ; K_{\text {Iff- }} 9^{-/-}, 1496 \pm 127 \mu \mathrm{m} ; n=\sim 9$ neurons per mouse, $n=6$ mice per genotype) (G); and dendritic spine density $\left(K l f-9^{+/+}, 1.037 \pm 0.232 ; K_{1 f-9^{-I-}}\right.$, $0.875 \pm 0.320 ; n=2$ distal segments on each of 4 granule neurons per mouse, $n=9$ mice per genotype) $(\boldsymbol{H})$. Shown is average \pm SD. Scale bar: $A, B, 500 \mu \mathrm{m} ; \boldsymbol{C}, \boldsymbol{D}, 100 \mu \mathrm{m}$.

and calbindin-positive cells in the developing DG (supplemental Fig. 3, available at www.jneurosci.org as supplemental material).

As a first step to glean insights into the functions of Klf- 9 in dentate granule neuron maturation, we compared Klf-9 expression with that of NeuroD and NeuroD2 in serial sections of the mouse hippocampus at P5, P10, and P20. We chose NeuroD and NeuroD2 as these TFs are expressed during the early and late phases of dentate granule neuron maturation, respectively (Pleasure et al., 2000). At P5 and P10, NeuroD and NeuroD2 are expressed in complementary gradients: NeuroD2 is expressed in an outside-in gradient with highest expression in mature granule cells (Fig. $2 K, L$ ), whereas NeuroD is expressed an inside-out gradient with highest expression in immature granule cells (Fig. $2 \mathrm{H}, \mathrm{I})$. In contrast, at P5, Klf-9 expression is restricted to the outer one-half of the granule cell layer in a high-to-low gradient that runs from the dorsal crest of the upper blade toward the inner blade (Fig. $2 N$ ). At P10, Klf-9 expression is seen only in the outer one-half of the granule cell layer (Fig. 2O). These observations suggest that $K l f-9$ is expressed in the earliest born population of dentate granule neurons. By P20, Klf-9 expression, like that of NeuroD2, expands toward the newly formed subgranular zone (SGZ) in which NeuroD expression is the highest (Fig. $2 J, M, P$ ). However, unlike NeuroD2, Klf-9 is not expressed in cells that have high levels of NeuroD transcripts (Fig. 2P, inset). The complete absence of Klf- 9 mRNAs in the inner one-half of the granule cell layer at both $\mathrm{P} 5$ and $\mathrm{P} 10$ indicates that $\mathrm{Klf}-9$ expression is induced after NeuroD2. However, Klf-9 transcripts were clearly detectable in the outer one-half of the granule cell layer of the DG of NeuroD2-null mice, suggesting that Klf-9 acts in a separate

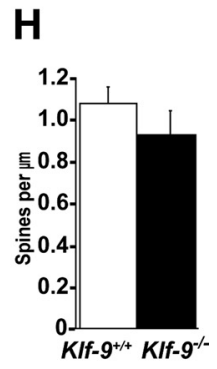

pathway (supplemental Fig. 2, available at www.jneurosci.org as supplemental material). The remarkable similarity between the expression pattern of Klf-9 with that of synaptic proteins such as synaptopodin in the developing DG (Czarnecki et al., 2005) suggests a role for Klf-9 in regulating late-phase neuronal maturation. Together, these results suggest that $K l f-9$ expression defines a novel window of terminal differentiation that is characterized by high $\mathrm{Neu}$ roD2 expression, presence of calbindin immunoreactivity, and absence of calretinin immunoreactivity (Fig. $2 A$ ).

\section{Dentate granule neurons lacking Klf-9 show prolonged expression of early-phase markers, altered spine maturation, and perturbed} electrophysiological properties during DG development

Based on our expression studies of $K l f-9$, we hypothesized that dentate granule neurons lacking $K l f-9$ would show impaired differentiation. To test this hypothesis, we performed three levels of analysis. First, we analyzed the expression of early-phase molecular markers such as NeuroD and calretinin in the DG of P20 Klf-9-null mice and wild-type controls. Second, we examined the effects of Klf-9 loss of function on development of dendritic spines of dentate granule neurons. Third, we analyzed passive membrane properties and AP responses in the developing DG of Klf-9-null mice and controls.

At P20, NeuroD transcripts and calretinin protein are found in the "immature" population of dentate granule neurons in the inner one-third of the granule cell layer (Fig. 3A,C). In Klf-9-null mice, we observed a significant expansion of the band of NeuroD transcripts and calretinin immunoreactivity in the granule cell layer (Fig. 3B,D;E,F, schematic). Quantification of the area of NeuroD expression and calretinin immunoreactivity revealed a $16.6 \pm 1.1 \%(p=0.016 ; n=3$ mice per group; paired $t$ tests $)$ and $18.7 \pm 1.88 \%(p=0.0004 ; n=3$ mice per group; unpaired $t$ tests) increase in Klf-9-null mice compared with controls, respectively. These results suggest that there is a larger population of immature dentate granule neurons in the developing DG of Klf9-null mice relative to controls.

To examine the role of Klf-9 in regulating the development of dendritic spines of dentate granule neurons, we perfusionfixed brains of P14 Klf-9-null and littermate controls and filled dentate granule neurons in the outer one-half of the dorsal/ upper blade of the granule cell layer with Lucifer yellow by iontophoresis. Confocal imaging followed by quantification of dendritic spines revealed a significant increase in dendritic spine density in Klf-9-null mice (Fig. $3 G, H)(p=0.002$, unpaired $t$ test). Analysis of spine morphology revealed that dentate granule neurons lacking Klf-9 have significantly longer dendritic spines (Fig. 3G, $I$ ) ( $p=0.019$, unpaired $t$ test). However, no difference in spine head width was observed (Fig. 
$3 G, J)(p>0.05)$, suggesting that Klf-9 loss of function selectively affects dendritic spine length. These results indicate that Klf-9 is required for normal development of dendritic spines of maturing dentate granule neurons in vivo.

Since the development of mossy fiber projections occurs during the first few weeks postnatally (Blaabjerg and Zimmer, 2007), we examined mossy fiber targeting in Klf-9-null mice at P20 by calbindin immunohistochemistry (Sahay et al., 2003). Quantification of the mossy fiber termination area and the length of the infrapyramidal tract did not reveal a difference between genotypes (Fig. 4A, $B)$ (data not shown). These results suggest that Klf-9 deficiency does not affect general targeting or axonal pathfinding of hippocampal mossy fibers.

We next asked whether the electrophysiological maturation of developing dentate granule neurons was affected by Klf-9 loss of function. Previous studies on granule cell maturation during DG development have shown that the transition from immature to mature stage is mirrored by decreases in input impedance, shift from depolarizing to hyperpolarizing resting membrane potential, and an increase in AP amplitude (Y. B. Liu et al., 1996). Therefore, we studied the passive and active electrical properties of granule neurons in the DG of Klf9-null mice and controls at P14-P17 (Fig. 5A-F). Surprisingly, no differences were observed in passive membrane properties between the two genotypes

(Fig. 5A-F). We next examined AP firing properties. Mature dentate granule neurons, unlike their immature counterparts, fire sustained trains of APs in response to multiple current injections. In response to square wave current injection ( $3 \mathrm{~s}$; $50 \mathrm{pA}$ ), we observed two distinct types of responses, based on which we classified a neuron in the developing DG as type A or type B. Type A neurons fired a single AP during the current step, whereas type B neurons exhibited sustained trains of APs (Fig. $3 K$, top panel). When analyzed based on location in the outer one-half of the DG, we find that $23 \%$ of cells are type A in Klf-9-null mice in contrast to only $4 \%$ in controls (Fig. $3 \mathrm{~K}$, bottom panel). Of cells in the inner one-half of the DG, $38 \%$ are type A in Klf-9-null mice compared with $21 \%$ in controls (Fig. $3 K$, bottom panel). The DG of Klf-9-null mice had a significantly greater proportion of type A cells than controls (Fig. $3 L)(p=0.029, n=9$ mice per group, unpaired $t$ test). These results indicate that $\mathrm{Klf}-9$ loss of function does not affect normal passive membrane properties but impairs the acquisition of normal AP response properties during dentate granule-neuronal maturation. Together, these results demonstrate that Klf-9 is required for discrete late-phase functions during dentate granule-neuronal maturation in the developing DG.
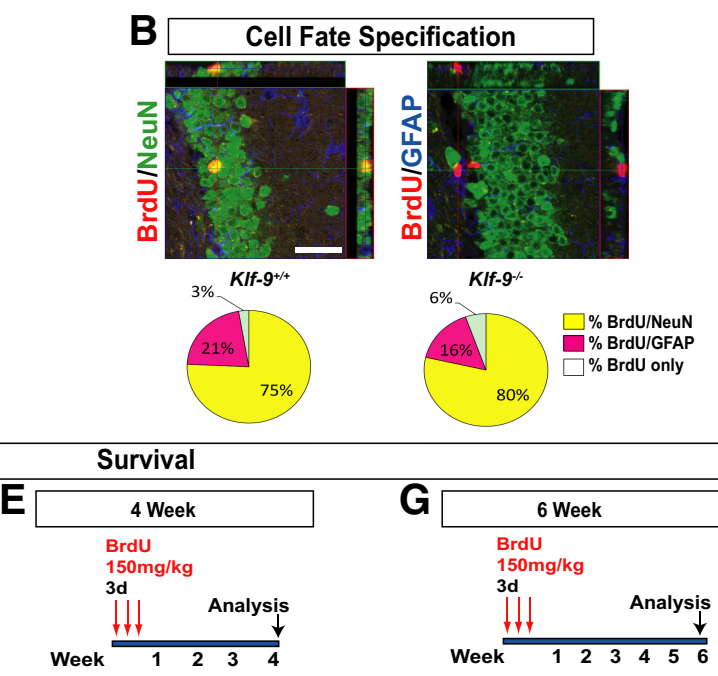

$\mathbf{F}$
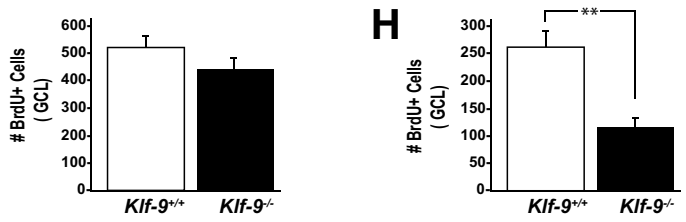

Figure 7. Adult KIf-9-null mice exhibit normal stem cell proliferation and cell fate specification but reduced survival of 4- to 6 -week-old adult-born neurons. A, Average total number of Ki-67+ cells in the GCL of KIf-9 $9^{-/-}$and $K I f-9^{+/+}$is not different etween KIf- $9^{+/+}$and KIf- $9^{-/-}$mice $\left(K I f-9^{+/+}, 828 \pm 12 ; K I f-9^{-/-}, 840 \pm 15.8 ; n=4 /\right.$ genotype). $\boldsymbol{B}$, Top, Representative

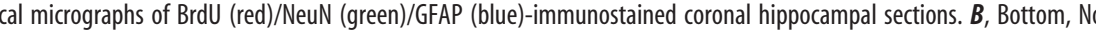
ast BrdU administration is not different between KIf-9 ${ }^{+/+}$and Klf-9 ${ }^{-1-}$ mice $\left(K l f-9^{+/+}, 2400 \pm 80 ; K l f-9^{-1-}, 2200 \pm 100\right.$

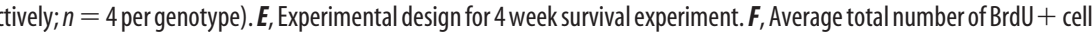
Klf- $9^{+/+}$mice $\left(K l f-9^{+/+}, 270 \pm 20.8 ; K l f-9^{-I-}, 114 \pm 15.9{ }^{* *} p=0.0005 ; n=3\right.$ mice per genotype). Results are average \pm

Developmentally born dentate granule neurons in adult Klf-9-null mice exhibit normal dendritic length and complexity and dendritic spine density

Adult Klf-9-null mice are healthy, fertile, and normal with respect to general brain architecture, cortical and hippocampal lamination, and formation of major axon tracts (Fig. 6A-D) (data not shown). The DG of adult Klf-9-null mice is grossly indistinguishable from controls, and there is no evidence for hypoplasia or disorganization of the granule cell layer (Fig. 6A,B). To determine whether developmentally generated dentate granule neurons lacking Klf-9 continue to show alterations in dendritic spine density in adulthood, we analyzed Golgi-impregnated dentate granule neurons residing in the outer one-half of the granule cell layer of the DG of P60 Klf-9-null and wild-type littermates. We focused on the outer one-half of the granule cell layer in P60 brains as it is populated primarily with developmentally generated neurons (Laplagne et al., 2006; Mongiat et al., 2009). Analysis of dendritic spine density did not reveal a difference between genotypes (Fig. $6 H$ ). These data suggest that alterations in spine density observed during DG development are corrected over time, presumably through compensatory homeostatic mechanisms. In addition, we also did not observe any differences in dendritic length or complexity of dentate granule neurons of Klf-9-null mice and controls (Fig. $6 E-G$ ). Since the DG is con- 
A
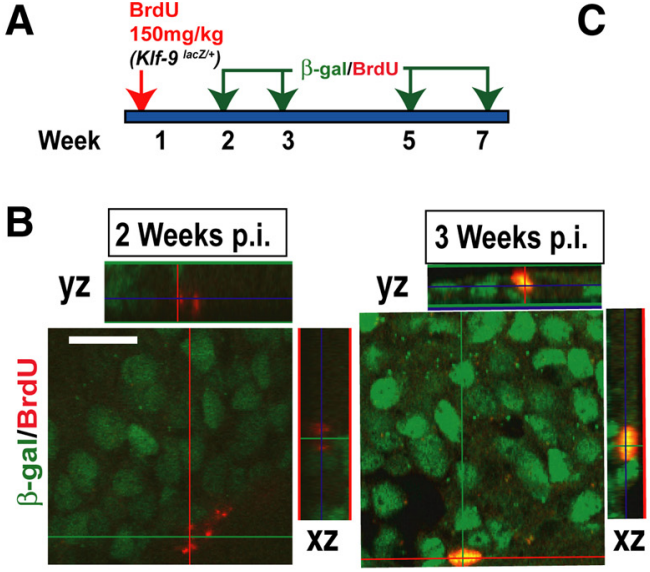

C
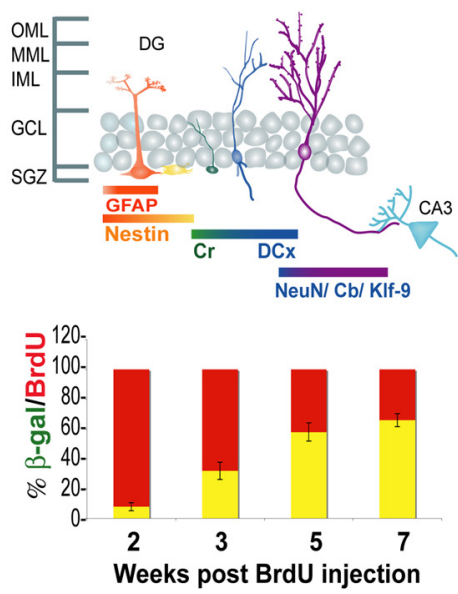

D

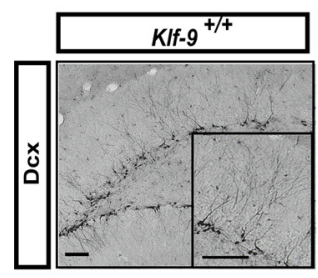

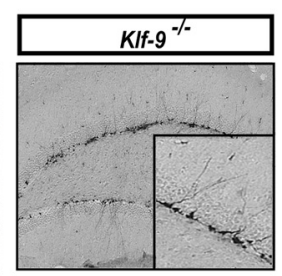

$\mathbf{F}$

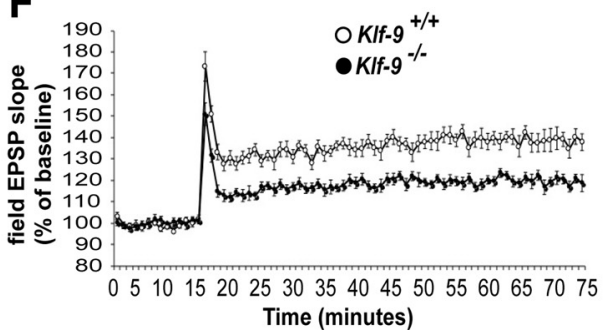

E
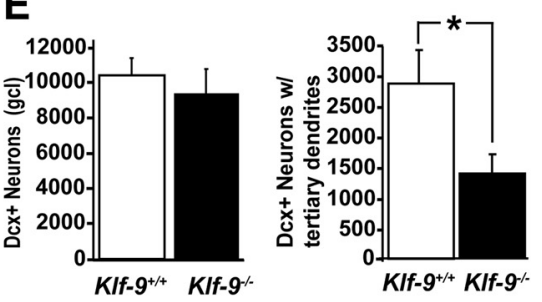

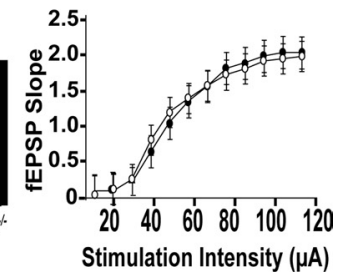

$8 A)$. $\beta$-Galactosidase immunoreactivity was clearly evident in adult-born neurons that were at least 3 weeks of age but not at 2 weeks after birth (see Fig. $8 B$ ). Since $\beta$-galactosidase immunoreactivity faithfully overlaps with the mature neuronal marker NeuN in the DG (data not shown) and recapitulates Klf-9 mRNA distribution, these birth-dating results suggest that adult-born neurons express Klf-9 when they begin to receive functional inputs (Espósito et al., 2005).

We first examined early-phase processes such as stem cell proliferation and cell fate specification in adult Klf-9-null mice and controls (Fig. 7A-F). Examination of stem cell proliferation using two different approaches, BrdU labeling and Ki67 immunohistochemistry, did not detect any differences between Klf-9-null mice compared with controls (Fig. 7A) (data not shown). In addition, the neuronal-to-glial ratio was also unaltered in Klf-9-null mice (Fig. 7B). Moreover, analysis of short-term survival of adultborn cells at $14 \mathrm{~d}$ (Fig. $7 C, D)$ or $30 \mathrm{~d}$ after BrdU injection did not reveal a difference between Klf-9-null mice and controls (Fig. $7 E, F$ ). These data demonstrate that early-phase processes underlying adult hippocampal neurogenesis are mostly intact in Klf-9-null mice and suggest that Klf-9 might function at later stages of neuronal maturation as predicted by its expression in differentiating adult-born neurons.

To investigate the effects of Klf-9 loss

Figure 8. Mice lacking Klf-9 exhibit impaired maturation of adult-born dentate granule neurons. $\boldsymbol{A}$, Experimental desig illustrating BrdU birthdating of Klf-9 expression using KIf-9+/lacZ mice. $B$, Representative confocal micrographs showing BrdU (red) and $\beta$-galactosidase (green) immunoreactivity at 2 ( $\boldsymbol{B}$, left) and 3 weeks ( $\boldsymbol{B}$, right) after injection of BrdU, respectively. $\boldsymbol{B}$, Bottom, Percentage of cells that express lac $Z$ at 2 weeks $(7.89 \pm 2.7 \%), 3$ weeks $(32.1 \pm 5.8 \%), 5$ weeks $(58.47 \pm 3.5 \%)$, and 7 weeks $(65.77 \pm 4.3 \%)$ after birth. C, Schematic summarizing Klf-9 expression with reference to known markers of adult-born dentate granule-neuronal maturation. D-G, Adult-born dentate granule neurons lacking KIf- 9 exhibit impaired maturation and reduced neurogenesis-dependent synaptic plasticity. $\boldsymbol{D}$, Representative images of DG of adult KIf-9 ${ }^{+/+}$(left) and KIf-9 ${ }^{-1-}$ (right) mice processed for Dcx immunoreactivity. Magnification: Inset, $40 \times$.E, Quantification showing the total number of $D c x+$ cells in KIf-9 $9^{+/+}$and KIf-9 $9^{-/-}$mice (left bar graph; KIf-9 ${ }^{+/+}, 10,183.3 \pm 1380 ; K I f-9^{-/-}, 9255.4 \pm 1488 ; p=0.7$ ) and fewer Dcx+

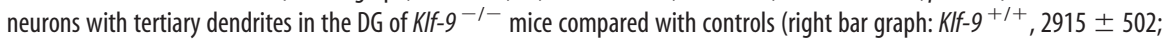
KIf-9 $9^{-I-}, 1383 \pm 357.6 ; p=0.02$, unpaired $t$ test). $\boldsymbol{F}$, Adult-born dentate granule neurons lacking Klf-9 exhibit reduced neurogenesis-dependent synaptic plasticity. KIf-9 $9^{-1-}$ mice exhibit significantly reduced ACSF-LTP (119.6 $\pm 2.5 \%$ of baseline) compared with KIf-9 $9^{+/+}$mice ( $138.3 \pm 3.8 \%$ of baseline). No difference in paired-pulse depression or input- output relationships between $K I f-9^{-1-}$ and KIf-9 ${ }^{+/+}$mice is observed. Results are mean \pm SEM. Scale bar: $\boldsymbol{B}, \boldsymbol{D}, 100 \mu \mathrm{m} .{ }^{*} p<0.02$.

tinuously modified by ongoing neurogenesis in adulthood, it is likely that genes that cell-autonomously affect maturation of dentate granule neurons during DG development also exert similar effects on adult-born neurons. Since Klf-9 is expressed in the adult DG (Fig. 1I), we sought to examine adult hippocampal neurogenesis in Klf-9-null mice.

\section{Impaired maturation of adult-born dentate granule neurons in Klf-9-null mice}

To begin to understand the role of Klf-9 in adult hippocampal neurogenesis, we first determined the onset of Klf-9 expression in adult-born neurons by administering the thymidine analog BrdU to $K l f-9^{\text {lacZ/+ }}$ mice and examining $\beta$-galactosidase immunoreactivity at 2, 3, 5, and 7 weeks after BrdU administration (see Fig. pocampal circuit (Couillard-Despres et al., 2005; Espósito et al., 2005). Quantification of the size of the Dcx population did not reveal any differences between the two genotypes (Fig. $8 E$, left bar graph). However, there were significantly fewer Dcx-expressing neurons with tertiary dendrites in Klf-9-null mice compared with wild-type littermates ( $p=0.02, n=9$ mice per genotype, unpaired $t$ test) (Fig. 8E, right bar graph). To control for the possibility that redistribution of Dcx or alterations in Dcx expression could account for the maturation phenotype in Klf-9-null mice, we used a complementary approach to quantify the Dcx population. We took advantage of a POMC- $\tau$-eGFP transgenic mouse line in which green fluorescent protein is expressed in the Dcx-positive population of neurons (http://www.gensat.org) (data not shown) and generated wild-type and Klf-9-null mice 
carrying the POMC- $\tau$-eGFP transgene (supplemental Fig. $4 A$, available at www. jneurosci.org as supplemental material). Analysis of GFP expression in these mice revealed significantly fewer $\tau$-eGFPexpressing neurons with tertiary dendrites in Klf-9-null mice ( $p=0.029, n=4$ mice per genotype, unpaired $t$ test) (supplemental Fig. $4 B$, available at www. jneurosci.org as supplemental material). The reduction in number of "mature" Dcx neurons but not the total number of Dcx-expressing neurons suggests that there are more "immature" Dcx neurons in the DG of adult Klf-9-null mice, a phenotype similar to the expansion in NeuroD expression observed during DG development.

The impaired maturation of Dcxpositive neurons suggested that these young neurons might not integrate successfully into the hippocampal circuit. Since neuronal integration has been shown to influence survival (Tashiro et al., 2006), we examined survival at a time point after Dcx expression (4-6 weeks). Klf-9-null mice showed a significant decrease in the number of adult-born neurons 6 weeks after the last BrdU injection (Fig. 7G,H). These results indicate that Klf-9 is not required for early-phase processes such as the production of adultborn neurons, but is essential for their normal integration into the local circuit.

\section{Reduced neurogenesis-dependent synaptic plasticity in DG of adult Klf-9-null mice}

Adult-born neurons exhibit a unique form of long-term potentiation (LTP), ACSF-LTP, which is induced by a weak stimulation paradigm and is insensitive to GABAergic inhibition (Snyder et al., 2001; Saxe et al., 2006; Bergami et al., 2008; Ge et al., 2008; Wang et al., 2008). Ablation of adult hippocampal neurogenesis by genetic or radiological methods completely abolishes ACSF-LTP (Snyder et al., 2001; Saxe et al., 2006). Several lines of evidence suggest that 4- to 6-week-old neurons are substrates for ACSF-LTP (Bergami et al., 2008; Ge et al., 2008). Since Klf-9 loss of function primarily affects the "mature" Dcx population and results in decreased survival of 4- to 6-week-old adult-born neurons, we investigated whether the functional integration of adult-born neurons was impaired in Klf-9-null mice by analyzing ACSF-LTP. Medial perforant path-DG recordings in Klf-9-null mice revealed a significant reduction in the magnitude of ACSF-LTP (Fig. $8 F$ ). We found no difference in measures of baseline synaptic transmission such as paired-pulse depression or input-output relationships between Klf-9-null mice and littermate controls (Fig. $8 F$ ). Together, these results suggest that $K l f-9$ is necessary for normal functional integration of adult-born neurons and neurogenesis-dependent synaptic plasticity.
Light-Dark Choice Test

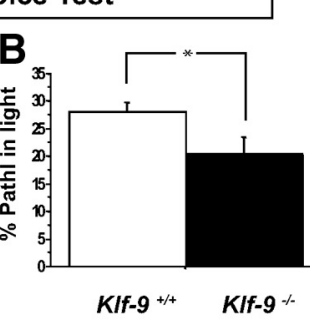

Open Field

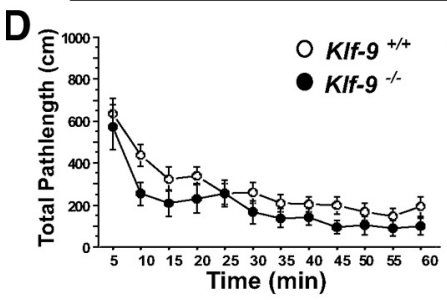

E
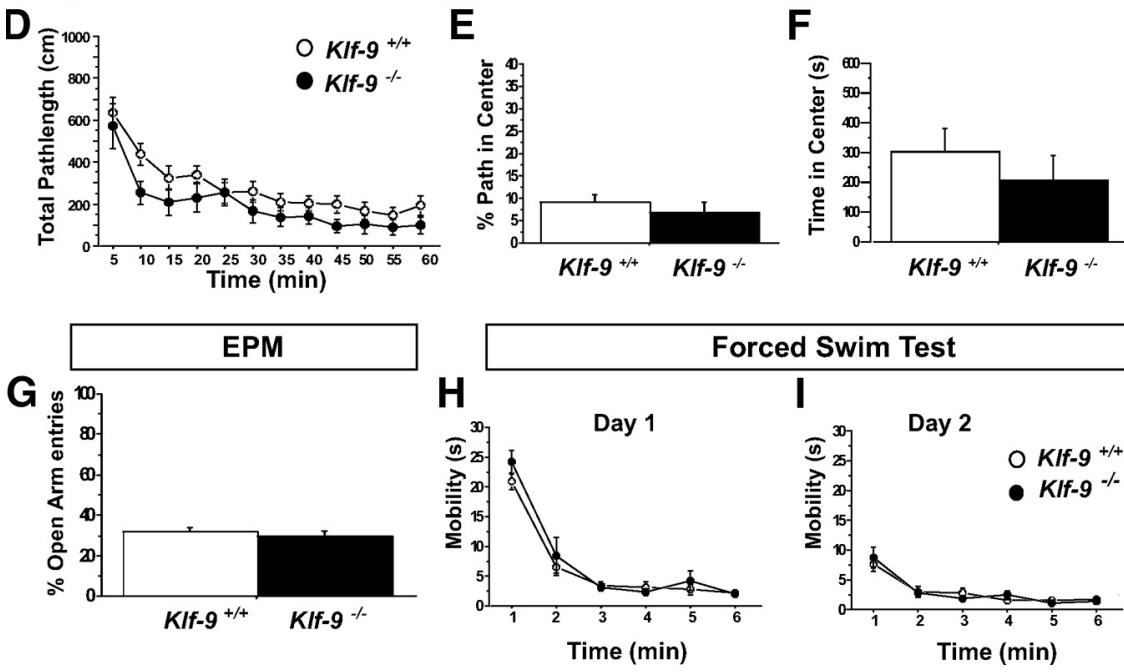

Forced Swim Test

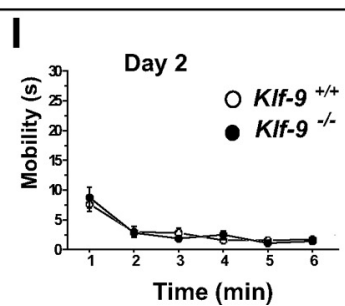

KIf-9-null mice exhibit normal behavior in multiple tests for anxiety-like and depression-like behavior, except in the light/dark test. $\boldsymbol{A}-\boldsymbol{H}$, Behavior of adult $K I f-9^{+/+}$and $K I f-9^{-/-}$mice in tests for anxiety-like $(\boldsymbol{A}-\boldsymbol{G})$ and depression-like behavior $\boldsymbol{H}) . \boldsymbol{A}, \boldsymbol{B}$, Light/dark choice test. $\boldsymbol{A}, K I f-9^{-/-}$mice spend less time spent in the light compartment than controls: $K l f-9^{+/+}$ percentage pathlength in the light compartment. KIf-9 ${ }^{+/+}, 28 \pm 1.7 \% ; K I f-9^{-I-}, 20.3 \pm 3.2 \% ; p=0.032$, unpaired $t$ test; $n=$ 11-15 per group. C, Novelty-suppressed feeding paradigm. KIf-9 ${ }^{-/-}$and $K I f-9^{+/+}$show equivalent latencies to feed in a nove analysis, Mantel-Cox log-rank test, $p=0.6$ ). No difference in home cage food consumption is observed; $p=0.2$, unpaired $t$ test; KIf-9 $9^{-1-}, 6.9 \pm 2.2 \% ; p=0.44$, unpaired $t$ test $)$ or "time in center" $\left(\boldsymbol{F} ; K I f-9^{+/+}, 302.4 \pm 78 \mathrm{~s} ; K l f-9^{-/-}, 205 \pm 86 \mathrm{~s}\right.$; , unpaired $t$ test) measures are observed between $K I f-9^{-1-}$ and $K I f-9^{+/+}$mice. $n=11-16$ per group. G, Elevated plus

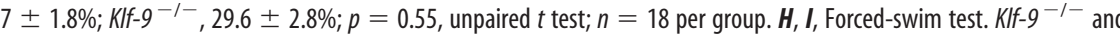
test. Repeated-measure ANOVA; $F_{(1,28)}<1 ; n=14-16$ per group. ${ }^{*} p=0.02(\boldsymbol{A})$, ${ }^{*} p=0.032(\boldsymbol{B})$.

Klf-9-null mice show subtle impairments in anxiety-like behavior and contextual fear discrimination learning

As previously stated, $K l f$-9-null mice are grossly indistinguishable from controls. Behavioral testing of Klf-9-null mice to measure changes in anxiety-like and depression-like behaviors revealed normal behavior in multiple paradigms (Fig. 9C-I) except in one test for anxiety-like behavior, the light/dark choice test (Fig. 9A,B). Specifically, Klf-9-null mice spent less time (Fig. 9A) and traveled less distance in the light compartment (Fig. 9B) suggestive of increased anxiety-like behavior. To determine the impact of deficits in Klf-9-dependent maturation on hippocampal-dependent learning, we tested Klf-9-null mice and littermate controls mice in a single trial contextual fear conditioning paradigm (Fig. 10 A). Both groups of mice showed comparable levels of conditioning to the training context (Fig. 10B), and this freezing behavior was specific to the training context as evidenced by negligible levels of 
A

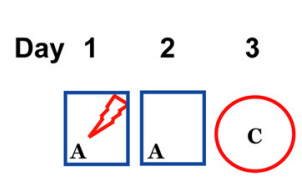

D

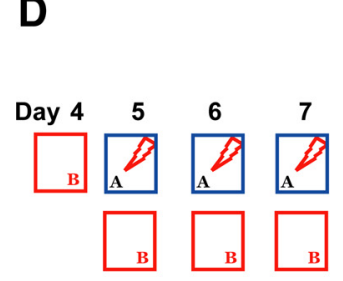

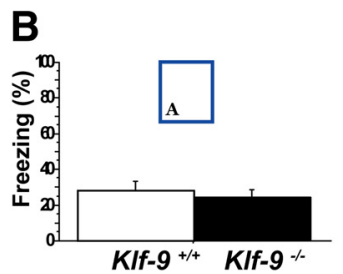

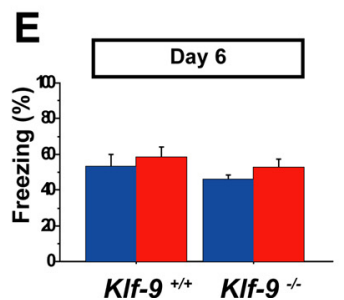

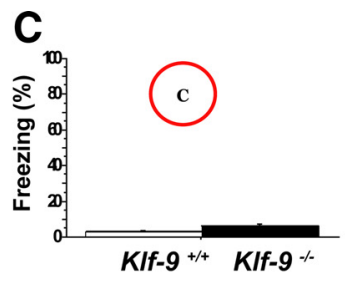

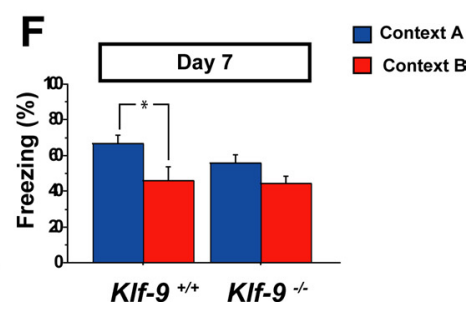

Figure 10. KIf-9-null mice are impaired in contextual fear discrimination learning. $\boldsymbol{A}-\boldsymbol{C}, K I f-9^{-1-}$ and $K I f-9^{+/+}$mice exhibit comparable levels of contextual fear conditioning. A, Mice were trained in context A and tested $24 \mathrm{~h}$ later in context A. On day 3 , freezing behavior was measured in a novel context to assess context-specificity of conditioning. $\boldsymbol{B}$, No difference in the level of freezing of KIf $-9^{-1-}$ and $K I f-9^{+/+}$in the training context is observed. Average freezing was as follows: KIf- $9^{+/+}, 28.33 \pm 5.1 \%$; $K I f-9^{-I-}, 24.54 \pm 4.13 \% ; p>0.05$, unpaired $t$ test. $C$, Both $K I f-9^{-1-}$ and $K I f-9^{+/+}$exhibit negligible levels of freezing in a novel context C. Average freezing was as follows: KIf-9 $9^{+/+}, 2.9 \pm 0.96 \% ; K_{I f-} 9^{-/-}, 6.1 \pm 1.29 \% ; p>0.05$, unpaired $t$ test. $D$, Experimental design of the contextual fear discrimination learning paradigm. $\boldsymbol{E}, 0$ n the second day of training (day 6$), K I f-9^{-1-}$ mice and controls exhibit comparable levels of freezing in both the training and similar contexts. $F, K l f-9^{-1-}$ mice, in contrast to controls, fail to discriminate between training context $A$ and similar context $B$ after $2 \mathrm{~d}$ of training. KIf- ${ }^{+/+}$: Average freezing in $A, 66.4 \pm 4.9 \% ; B, 45 \pm 7.7 \% ; p<0.05$, unpaired $t$ test. Klf-9 ${ }^{-1-}$ : Average freezing in $A, 55.8 \pm 4.3 \% ; B, 44.3 \pm 3.8 \% ; p>$ 0.05 , unpaired $t$ test. $n=9\left(\right.$ KIf-9 $\left.{ }^{+/+}\right)$and $16\left(K l f-9^{-/-}\right)$. Results are mean \pm SEM. ${ }^{*} p<0.05$.

freezing in a novel context C (Fig. 10C). Next, we tested their performance in a contextual fear discrimination learning paradigm (Fig. 10D) (Frankland et al., 1998; Wang et al., 2009). In contrast to the control group that learned to distinguish between the two contexts (Fig. 10F), Klf-9-null mice exhibited similar levels of freezing in the two contexts. This impairment in discrimination between the two contexts is unlikely to be attributable to a ceiling effect of freezing in the training context as Klf-9-null mice show comparable increases in freezing levels in a three toneshock fear conditioning paradigm (supplemental Fig. 5, available at www.jneurosci.org as supplemental material). Furthermore, freezing levels in the training context were not significantly different between the two genotypes ( $p=0.14$, unpaired $t$ test) (Fig. $10 F)$. Together, these results suggest that, although Klf-9dependent neuronal maturation is not required for contextual fear conditioning, but it maybe necessary for normal contextual fear discrimination learning.

\section{Discussion}

Studies of transcriptional regulators of dentate granule neuronal maturation have generated considerable insights into the mechanisms underlying the early phase of maturation. In contrast, much less is known about TFs that regulate the late phase of maturation when dentate granule neurons achieve full connectivity, acquire functional properties, and contribute to encoding in the DG. Consistent with the functions of Klf- 9 as a late-phase regulator of neuronal maturation, the DG of Klf-9-null mice develops normally compared with that of mouse mutants lacking early-phase TFs, which show severe defects in DG formation (Miyata et al., 1999; Zhao et al., 1999; M. Liu et al., 2000; Oldekamp et al., 2004; Shen et al., 2006; Galichet et al., 2008). Klf-9 loss of function primarily affects late-phase processes such as dendritic spine formation and AP response properties of dentate granule neurons during DG development. In adulthood, Klf-9null mice exhibit normal levels of stem cell proliferation, cell fate specification, and short-term survival of adult-born neurons compared with controls. However, adultborn neurons lacking $K l f-9$ are impaired in their maturation as evidenced by reduced numbers of "mature" Dcx-positive neurons and decreased ACSF-LTP in Klf9-null mice. Thus, the requirement for Klf-9 during the late phase of neuronal maturation appears to be conserved between DG development and adulthood. However, there are some differences between the phenotypes of developmentally born and adult-born neurons in Klf9-null mice. For example, although Golgi impregnation did not reveal a difference in dendritic complexity of older, presumably developmentally generated, dentate granule neurons at P60, there are fewer adult-born neurons with complex dendritic trees in Klf-9-null mice. It therefore is important to determine whether the mechanisms by which Klf-9 regulates latephase maturation during DG development and adult neurogenesis are also conserved.

There is growing evidence suggesting that Klfs act as part of a cascade to orchestrate different stages of maturation in various cell types. This is perhaps best exemplified by the sequential expression of Klf-4, Klf-5, Klf-7, $K l f-9$, and $K l f-13$ at discrete stages of postnatal thymocyte differentiation (Tabrizifard et al., 2004). In embryonic stem cells, another network of Klfs, Klf-2, Klf-4, and Klf-5, has been shown to be required for maintenance of pluripotency (Jiang et al., 2008). Since Klf-9 expression persists in the developing DG of NeuroD2 knock-outs, it is unlikely that $K l f-9$ is a transcriptional target of NeuroD2. Instead, we propose that Klf-9 functions as part of a Klf cascade involved in distinct stages of dentate granule neuronal maturation. Altered expression of several Klfs in the DG of Klf9-null mice (A. Sahay and R. Hen, unpublished results) lends support to this hypothesis.

An important caveat in interpreting our findings on the role of Klf-9 in adult hippocampal neurogenesis is that we have relied on Klf-9-null mice for this study. Therefore, it is difficult to dissociate the cell-autonomous requirements of Klf- 9 in adult-born neurons from the non-cell-autonomous contributions of Klf-9 in other cell types such as mature dentate granule neurons and neurons in the medial entorhinal cortex. Indeed, recent studies have shown that manipulation of specific genes such as cdk5 or Gadd45b in mature dentate granule neurons impacts proliferation in the adult DG non-cell autonomously (Lagace et al., 2008; Ma et al., 2009). Caveats notwithstanding, several observations suggest that Klf-9 may play a cell-autonomous role in regulating late-phase maturation of adult-born neurons. First, early-phase processes underlying adult hippocampal neurogenesis such as stem cell proliferation, cell fate specification, and short-term survival are intact in Klf-9-null mice. Second, the phenotype of adult-born neurons lacking Klf-9 correlates with the expression profile of Klf-9 during maturation of adult-born neurons. Together with the normal brain architecture and basal synaptic transmission at medial perforant pathdentate granule cell synapses observed in adult Klf-9-null mice, these observations suggest that hippocampal network properties are not profoundly altered as a consequence of de- 
velopmental Klf-9 loss of function. Nevertheless, cell typespecific manipulations of Klf-9 using genetic approaches are essential to definitively address the cell-autonomous and noncell-autonomous contributions of Klf-9 to late-phase maturation of adult-born neurons.

The late-phase dentate granule-neuronal maturation phenotypes observed in Klf-9-null mice could reflect a failure to activate a repertoire of late-phase gene expression and/or repress a gene expression program associated with early-phase maturation. In accord with these predictions, transcriptional profiling of the DG of Klf-9-null mice revealed both upregulation and downregulation of gene expression (A. Sahay and R. Hen, unpublished results). Interestingly, potential targets of Klf-9 include genes involved in synaptic physiology and dendritic spine maturation such as neuronal pentraxin-2 (Xu et al., 2003), lin7b (Olsen et al., 2006), the sodium channel Nav1.3 (Yu and Catterall, 2003), T-type calcium channel (CaV3.1) (Huguenard, 1996), Kv channel interacting protein 4 (KChiP4) (Rhodes et al., 2004), and the potassium channel KCNA4 (Luján et al., 2003). T-type calcium channels and NR2B subtype of NMDA receptors are thought to contribute to the increased excitability of 4- to 6-week-old adult-born neurons (Schmidt-Hieber et al., 2004; $\mathrm{Ge}$ et al., 2007). It is therefore possible that the reduced neurogenesis-dependent synaptic plasticity seen in Klf-9-null mice is attributable in part to decreased expression of some of these genes. Thus, the late-phase restricted actions of Klf- 9 may regulate both functional integration as well as excitability of adult-born neurons.

Deficiencies in Klf-9-dependent neural circuit maturation have little impact on exploratory behavior, anxiety and depressionlike behaviors, and cued fear conditioning. Specifically, Klf-9-null mice show an increased anxiety-like phenotype only in the light/dark choice test. In tests for hippocampal-dependent learning such as contextual fear conditioning, Klf-9-null mice perform as well as controls, regardless of the protocol used [one shock-context pairing (Fig. $10 A-C$ ) or a three tone-shock pairing (supplemental Fig. 5, available at www.jneurosci.org as supplemental material)]. We do not observe deficits in acquisition of contextual fear conditioning in Klf-9-null mice in contrast to a previous report (Morita et al., 2003). Differences in strain or training protocols (foreground vs background fear conditioning) could underlie these observed differences. However, our studies reveal a subtle impairment in contextual fear discrimination learning in Klf-9-null mice that is similar to previous studies on mice with perturbed hippocampal functions (Wang et al., 2009). Recent studies have suggested that the DG is most likely to be recruited under conditions when the animal has to discriminate between similar contexts (Leutgeb et al., 2007; McHugh et al., 2007). Additionally, adult-born neurons have been shown to contribute to pattern separation (A. Sahay and R. Hen, unpublished observations). Thus, the contextual fear discrimination learning deficits seen in Klf-9-null mice may be, in part, attributable to perturbations in DG functions such as pattern separation.

In summary, our studies have identified a novel transcriptional regulator of dentate granule neuron maturation both during DG development and in adult hippocampal neurogenesis. Klf-9 is necessary specifically for late-phase maturation of dentate granule neurons and contributes to DG-dependent learning. Cell type-restricted manipulations of Klf-9 combined with functional analysis of the mechanisms by which Klf- 9 regulates late-phase maturation of dentate granule neurons are likely to generate insights into molecular substrates of DG-dependent functions.

\section{References}

Altman J, Bayer SA (1990) Migration and distribution of two populations of hippocampal granule cell precursors during the perinatal and postnatal periods. J Comp Neurol 301:365-381.

Altman J, Das GD (1965) Autoradiographic and histological evidence of postnatal hippocampal neurogenesis in rats. J Comp Neurol 124:319-335.

Ambrogini P, Cuppini R, Ferri P, Mancini C, Ciaroni S, Voci A, Gerdoni E, Gallo G (2005) Thyroid hormones affect neurogenesis in the dentate gyrus of adult rat. Neuroendocrinology 81:244-253.

Barbosa AC, Kim MS, Ertunc M, Adachi M, Nelson ED, McAnally J, Richardson JA, Kavalali ET, Monteggia LM, Bassel-Duby R, Olson EN (2008) MEF2C, a transcription factor that facilitates learning and memory by negative regulation of synapse numbers and function. Proc Natl Acad Sci U S A 105:9391-9396.

Bender RA, Lauterborn JC, Gall CM, Cariaga W, Baram TZ (2001) Enhanced CREB phosphorylation in immature dentate gyrus granule cells precedes neurotrophin expression and indicates a specific role of CREB in granule cell differentiation. Eur J Neurosci 13:679-686.

Bergami M, Rimondini R, Santi S, Blum R, Götz M, Canossa M (2008) Deletion of TrkB in adult progenitors alters newborn neuron integration into hippocampal circuits and increases anxiety-like behavior. Proc Natl Acad Sci U S A 105:15570-15575.

Blaabjerg M, Zimmer J (2007) The dentate mossy fibers: structural organization, development and plasticity. Prog Brain Res 163:85-107.

Brandt MD, Jessberger S, Steiner B, Kronenberg G, Reuter K, Bick-Sander A, von der Behrens W, Kempermann G (2003) Transient calretinin expression defines early postmitotic step of neuronal differentiation in adult hippocampal neurogenesis of mice. Mol Cell Neurosci 24:603-613.

Carlson CM, Endrizzi BT, Wu J, Ding X, Weinreich MA, Walsh ER, Wani MA, Lingrel JB, Hogquist KA, Jameson SC (2006) Kruppel-like factor 2 regulates thymocyte and T-cell migration. Nature 442:299-302.

Couillard-Despres S, Winner B, Schaubeck S, Aigner R, Vroemen M, Weidner N, Bogdahn U, Winkler J, Kuhn HG, Aigner L (2005) Doublecortin expression levels in adult brain reflect neurogenesis. Eur J Neurosci 21:1-14.

Czarnecki K, Haas CA, Bas Orth C, Deller T, Frotscher M (2005) Postnatal development of synaptopodin expression in the rodent hippocampus. J Comp Neurol 490:133-144.

Denver RJ, Ouellet L, Furling D, Kobayashi A, Fujii-Kuriyama Y, Puymirat J (1999) Basic transcription element-binding protein (BTEB) is a thyroid hormone-regulated gene in the developing central nervous system. Evidence for a role in neurite outgrowth. J Biol Chem 274:23128-23134.

Eriksson PS, Perfilieva E, Björk-Eriksson T, Alborn AM, Nordborg C, Peterson DA, Gage FH (1998) Neurogenesis in the adult human hippocampus. Nat Med 4:1313-1317.

Espósito MS, Piatti VC, Laplagne DA, Morgenstern NA, Ferrari CC, Pitossi FJ, Schinder AF (2005) Neuronal differentiation in the adult hippocampus recapitulates embryonic development. J Neurosci 25:10074-10086.

Frankland PW, Cestari V, Filipkowski RK, McDonald RJ, Silva AJ (1998) The dorsal hippocampus is essential for context discrimination but not for contextual conditioning. Behav Neurosci 112:863-874.

Galichet C, Guillemot F, Parras CM (2008) Neurogenin 2 has an essential role in development of the dentate gyrus. Development 135:2031-2041.

Ge S, Yang CH, Hsu KS, Ming GL, Song H (2007) A critical period for enhanced synaptic plasticity in newly generated neurons of the adult brain. Neuron 54:559-566.

Ge S, Sailor KA, Ming GL, Song H (2008) Synaptic integration and plasticity of new neurons in the adult hippocampus. J Physiol 586:3759-3765.

Good KL, Tangye SG (2007) Decreased expression of Kruppel-like factors in memory B cells induces the rapid response typical of secondary antibody responses. Proc Natl Acad Sci U S A 104:13420-13425.

Gross C, Zhuang X, Stark K, Ramboz S, Oosting R, Kirby L, Santarelli L, Beck S, Hen R (2002) Serotonin1A receptor acts during development to establish normal anxiety-like behaviour in the adult. Nature 416:396-400.

Hodge RD, Kowalczyk TD, Wolf SA, Encinas JM, Rippey C, Enikolopov G, Kempermann G, Hevner RF (2008) Intermediate progenitors in adult hippocampal neurogenesis: Tbr2 expression and coordinate regulation of neuronal output. J Neurosci 28:3707-3717.

Huguenard JR (1996) Low-threshold calcium currents in central nervous system neurons. Annu Rev Physiol 58:329-348.

Jiang J, Chan YS, Loh YH, Cai J, Tong GQ, Lim CA, Robson P, Zhong S, Ng 
HH (2008) A core Klf circuitry regulates self-renewal of embryonic stem cells. Nat Cell Biol 10:353-360.

Kaczynski J, Cook T, Urrutia R (2003) Sp1- and Kruppel-like transcription factors. Genome Biol 4:206.

Khawaja X, Xu J, Liang JJ, Barrett JE (2004) Proteomic analysis of protein changes developing in rat hippocampus after chronic antidepressant treatment: implications for depressive disorders and future therapies. J Neurosci Res 75:451-460.

Lagace DC, Benavides DR, Kansy JW, Mapelli M, Greengard P, Bibb JA, Eisch AJ (2008) Cdk5 is essential for adult hippocampal neurogenesis. Proc Natl Acad Sci U S A 105:18567-18571.

Laplagne DA, Espósito MS, Piatti VC, Morgenstern NA, Zhao C, van Praag H, Gage FH, Schinder AF (2006) Functional convergence of neurons generated in the developing and adult hippocampus. PLoS Biol 4:e409.

Leutgeb JK, Leutgeb S, Moser MB, Moser EI (2007) Pattern separation in the dentate gyrus and CA3 of the hippocampus. Science 315:961-966.

Lin Y, Bloodgood BL, Hauser JL, Lapan AD, Koon AC, Kim TK, Hu LS, Malik AN, Greenberg ME (2008) Activity-dependent regulation of inhibitory synapse development by Npas4. Nature 455:1198-1204.

Liu M, Pleasure SJ, Collins AE, Noebels JL, Naya FJ, Tsai MJ, Lowenstein DH (2000) Loss of BETA2/NeuroD leads to malformation of the dentate gyrus and epilepsy. Proc Natl Acad Sci U S A 97:865-870.

Liu X, Tilwalli S, Ye G, Lio PA, Pasternak JF, Trommer BL (2000) Morphologic and electrophysiologic maturation in developing dentate gyrus granule cells. Brain Res 856:202-212.

Liu YB, Lio PA, Pasternak JF, Trommer BL (1996) Developmental changes in membrane properties and postsynaptic currents of granule cells in rat dentate gyrus. J Neurophysiol 76:1074-1088.

Luján R, de Cabo de la Vega C, Dominguez del Toro E, Ballesta JJ, Criado M, Juiz JM (2003) Immunohistochemical localization of the voltage-gated potassium channel subunit Kv1.4 in the central nervous system of the adult rat. J Chem Neuroanat 26:209-224.

Ma DK, Jang MH, Guo JU, Kitabatake Y, Chang ML, Pow-Anpongkul N, Flavell RA, Lu B, Ming GL, Song H (2009) Neuronal activity-induced Gadd45b promotes epigenetic DNA demethylation and adult neurogenesis. Science 323:1074-1077.

Maekawa M, Takashima N, Arai Y, Nomura T, Inokuchi K, Yuasa S, Osumi N (2005) Pax6 is required for production and maintenance of progenitor cells in postnatal hippocampal neurogenesis. Genes Cells 10:1001-1014.

McHugh TJ, Jones MW, Quinn JJ, Balthasar N, Coppari R, Elmquist JK, Lowell BB, Fanselow MS, Wilson MA, Tonegawa S (2007) Dentate gyrus NMDA receptors mediate rapid pattern separation in the hippocampal network. Science 317:94-99.

Miyata T, Maeda T, Lee JE (1999) NeuroD is required for differentiation of the granule cells in the cerebellum and hippocampus. Genes Dev 13:1647-1652.

Mongiat LA, Espósito MS, Lombardi G, Schinder AF (2009) Reliable activation of immature neurons in the adult hippocampus. PLoS One 4:e5320.

Morita M, Kobayashi A, Yamashita T, Shimanuki T, Nakajima O, Takahashi S, Ikegami S, Inokuchi K, Yamashita K, Yamamoto M, Fujii-Kuriyama Y (2003) Functional analysis of basic transcription element binding protein by gene targeting technology. Mol Cell Biol 23:2489-2500.

Nikolcheva T, Pyronnet S, Chou SY, Sonenberg N, Song A, Clayberger C, Krensky AM (2002) A translational rheostat for RFLAT-1 regulates RANTES expression in T lymphocytes. J Clin Invest 110:119-126.

Oldekamp J, Kraemer N, Alvarez-Bolado G, Skutella T (2004) bHLH gene expression in the Emx2-deficient dentate gyrus reveals defective granule cells and absence of migrating precursors. Cereb Cortex 14:1045-1058.

Olsen O, Moore KA, Nicoll RA, Bredt DS (2006) Synaptic transmission regulated by a presynaptic MALS/Liprin-alpha protein complex. Curr Opin Cell Biol 18:223-227.

Olson JM, Asakura A, Snider L, Hawkes R, Strand A, Stoeck J, Hallahan A, Pritchard J, Tapscott SJ (2001) NeuroD2 is necessary for development and survival of central nervous system neurons. Dev Biol 234:174-187.

Pleasure SJ, Collins AE, Lowenstein DH (2000) Unique expression patterns of cell fate molecules delineate sequential stages of dentate gyrus development. J Neurosci 20:6095-6105.

Rahimi O, Claiborne BJ (2007) Morphological development and maturation of granule neuron dendrites in the rat dentate gyrus. Prog Brain Res 163:167-181.

Rhodes KJ, Carroll KI, Sung MA, Doliveira LC, Monaghan MM, Burke SL, Strassle BW, Buchwalder L, Menegola M, Cao J, An WF, Trimmer JS (2004) KChIPs and Kv4 alpha subunits as integral components of A-type potassium channels in mammalian brain. J Neurosci 24:7903-7915.

Rudy JW, O’Reilly RC (1999) Contextual fear conditioning, conjunctive representations, pattern completion, and the hippocampus. Behav Neurosci 113:867-880.

Sahay A, Molliver ME, Ginty DD, Kolodkin AL (2003) Semaphorin 3F is critical for development of limbic system circuitry and is required in neurons for selective CNS axon guidance events. J Neurosci 23:6671-6680.

Santarelli L, Saxe M, Gross C, Surget A, Battaglia F, Dulawa S, Weisstaub N, Lee J, Duman R, Arancio O, Belzung C, Hen R (2003) Requirement of hippocampal neurogenesis for the behavioral effects of antidepressants. Science 301:805-809.

Saxe MD, Battaglia F, Wang JW, Malleret G, David DJ, Monckton JE, Garcia AD, Sofroniew MV, Kandel ER, Santarelli L, Hen R, Drew MR (2006) Ablation of hippocampal neurogenesis impairs contextual fear conditioning and synaptic plasticity in the dentate gyrus. Proc Natl Acad Sci U S A 103:17501-17506.

Schmidt-Hieber C, Jonas P, Bischofberger J (2004) Enhanced synaptic plasticity in newly generated granule cells of the adult hippocampus. Nature 429:184-187.

Shen L, Nam HS, Song P, Moore H, Anderson SA (2006) FoxG1 haploinsufficiency results in impaired neurogenesis in the postnatal hippocampus and contextual memory deficits. Hippocampus 16:875-890.

Snyder JS, Kee N, Wojtowicz JM (2001) Effects of adult neurogenesis on synaptic plasticity in the rat dentate gyrus. J Neurophysiol 85:2423-2431.

Song H, Kempermann G, Overstreet Wadiche L, Zhao C, Schinder AF, Bischofberger J (2005) New neurons in the adult mammalian brain: synaptogenesis and functional integration. J Neurosci 25:10366-10368.

Tabrizifard S, Olaru A, Plotkin J, Fallahi-Sichani M, Livak F, Petrie HT (2004) Analysis of transcription factor expression during discrete stages of postnatal thymocyte differentiation. J Immunol 173:1094-1102.

Tashiro A, Sandler VM, Toni N, Zhao C, Gage FH (2006) NMDA-receptormediated, cell-specific integration of new neurons in adult dentate gyrus. Nature 442:929-933.

Wang JW, David DJ, Monckton JE, Battaglia F, Hen R (2008) Chronic fluoxetine stimulates maturation and synaptic plasticity of adult-born hippocampal granule cells. J Neurosci 28:1374-1384.

Wang SH, Teixeira CM, Wheeler AL, Frankland PW (2009) The precision of remote context memories does not require the hippocampus. Nat Neurosci 12:253-255.

Xu D, Hopf C, Reddy R, Cho RW, Guo L, Lanahan A, Petralia RS, Wenthold RJ, O'Brien RJ, Worley P (2003) Narp and NP1 form heterocomplexes that function in developmental and activity-dependent synaptic plasticity. Neuron 39:513-528.

Yu FH, Catterall WA (2003) Overview of the voltage-gated sodium channel family. Genome Biol 4:207.

Zagulska-Szymczak S, Filipkowski RK, Kaczmarek L (2001) Kainateinduced genes in the hippocampus: lessons from expression patterns. Neurochem Int 38:485-501.

Zhang JS, Moncrieffe MC, Kaczynski J, Ellenrieder V, Prendergast FG, Urrutia R (2001) A conserved alpha-helical motif mediates the interaction of Sp1-like transcriptional repressors with the corepressor mSin3A. Mol Cell Biol 21:5041-5049.

Zhao C, Teng EM, Summers RG Jr, Ming GL, Gage FH (2006) Distinct morphological stages of dentate granule neuron maturation in the adult mouse hippocampus. J Neurosci 26:3-11.

Zhao Y, Sheng HZ, Amini R, Grinberg A, Lee E, Huang S, Taira M, Westphal $\mathrm{H}$ (1999) Control of hippocampal morphogenesis and neuronal differentiation by the LIM homeobox gene Lhx5. Science 284:1155-1158. 